\title{
Palladium Catalyzed Cross-Coupling Reactions of Heterocyclic Silanolates with Substituted Aryl Iodides and Bromides
}

\author{
Scott E. Denmark* and John D. Baird \\ Roger Adams Laboratory, Department of Chemistry, University of Illinois, Urbana, Illinois \\ 61801
}

Table of Contents

\section{SUPPORTING INFORMATION}

General Experimental

Page

Literature Preparations

Preparation of Silanols

General Procedures

Experimental Procedures

References

\section{General Experimental:}

Reactions were conducted using glassware that had been oven-dried for at least $12 \mathrm{~h}$ or flame-dried under vacuum. Syringes and needles were dried for at least $12 \mathrm{~h}$ and flushed with argon prior to use. All reactions were conducted under an atmosphere of dry argon using a drying tube equipped with phosphorus pentoxide and calcium sulfate. Solvents used for extraction were reagent grade, and chromatography solvents were reagent grade except for ethyl acetate which was technical grade and distilled using $\mathrm{K}_{2} \mathrm{CO}_{3}$ as the drying agent. Reaction solvent toluene (Fisher, ACS grade) was dried by percolation through a column packed with neutral alumina and a column packed with Q5 reactant, a supported copper catalyst for scavenging oxygen, under a positive pressure of argon. $n$-BuLi was titrated using a modification of Gilman's double titration method. ${ }^{1}$ All reaction temperatures were measured internally with Teflon coated thermocouple probes.

All ${ }^{1} \mathrm{H}$ NMR, ${ }^{13} \mathrm{C}$ NMR, and ${ }^{19} \mathrm{~F}$ NMR spectra were obtained on Varian Unity 400 and Unity $500 \mathrm{MHz}$ spectrometers using deuterochloroform with residual chloroform as the internal reference $\left(\delta 7.26 \mathrm{ppm},{ }^{1} \mathrm{H} ; \delta 77.0 \mathrm{ppm},{ }^{13} \mathrm{C}\right.$ ), deuterobenzene with residual benzene as the 
internal reference $\left(\delta 7.15 \mathrm{ppm},{ }^{1} \mathrm{H} ; \delta 128.62 \mathrm{ppm},{ }^{13} \mathrm{C}\right)$ or deuteriotetrahydrofuran with residual tetrahydrofuran as the internal reference $\left(\delta 3.58 \mathrm{ppm},{ }^{1} \mathrm{H} ; \delta 67.4 \mathrm{ppm},{ }^{13} \mathrm{C}\right)$. Hexafluorobenzene was used as an internal reference for ${ }_{19} \mathrm{~F}$ NMR $\left(-160.0 \mathrm{ppm},{ }^{19} \mathrm{~F}\right)$. All chemical shifts are reported in ppm ( $\delta$ ) while multiplicities are indicated as s (singlet), $\mathrm{d}$ (doublet), $\mathrm{t}$ (triplet), q (quartet), or $\mathrm{m}$ (multiplet). All coupling constants $(J)$ are reported in Hertz. Infrared spectra (IR) were obtained using a Mattson Galaxy 5020 spectrophotometer, and peaks are reported in reciprocal cm along with relative signal intensities: s (strong); m (medium); w (weak). Mass spectrometry data was performed by the University of Illinois School for Chemical Sciences and molecular ion peaks are listed with relative abundances. Elemental analyses were conducted by the University of Illinois Microanalytical Service Laboratory. Retention factors, $R_{f}$, are reported for analytical thin layer chromatography performed on Merck silica gel plates treated with F-254 indicator. Visualization was accomplished by UV light or aqueous $\mathrm{KMnO}_{4}$ solution. Column chromatography was conducted using 230-400 mesh silica gel purchased from Silicycle using the eluent and pressure given.

Analytical capillary gas chromatography (GC) was performed on a Hewlett Packard 5890 Series II instrument equipped with a flame ionization detector $\left(\mathrm{H}_{2}\right.$ carrier gas, $\left.1 \mathrm{~mL} / \mathrm{min}\right)$ and a HP-5 50-m column cross-linked 5\%-Phenyl methyl silicone gum stationary phase. The following program was used for GC analysis: initial temperature of $100{ }^{\circ} \mathrm{C}$ and an initial time of $1 \mathrm{~min}$. A ramp of $50{ }^{\circ} \mathrm{C} / \mathrm{min}$ was employed with a final temperature of $250{ }^{\circ} \mathrm{C}$ and a final time of 15 min. The injector port was set to $250{ }^{\circ} \mathrm{C}$ and the detector port at $300{ }^{\circ} \mathrm{C}$.

Commercial reagents were purified by recrystallization or distillation before use. Distillations were performed using a short-path, $3 \mathrm{~cm}$, Vigreaux column under reduced pressure. Bulb-to-bulb distillations were conducted using a Büchi GKR-50 Kugelrohr apparatus at the pressure specified. All reported boiling points are recorded air-bath temperatures (ABT). Melting points were conducted in vacuum-sealed glass tubes using a Thomas-Hoover Uni-Melt ${ }^{\mathrm{TM}}$ melting point apparatus and are corrected. Sodium hydride was purchased from Aldrich as a $60 \%$ suspension in mineral oil which was washed with hexanes and titrated using No D-NMR spectroscopy. $^{2}$

\section{Literature Preparations:}

$N$-Boc(2-indolyl)dimethylsilanol ${ }^{3}$ was prepared according to the literature procedure. 


\section{Preparation of $N$-Boc(2-pyrrolyl)dimethylsilanol (4)}

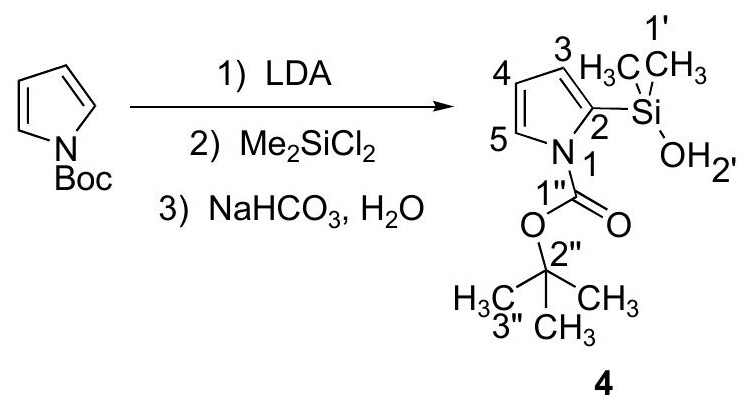

To a flame-dried, three-necked, 250-mL, round-bottomed flask fitted with an argon inlet adaptor, thermocouple, magnetic stir bar and septum was placed $3.00 \mathrm{~g}$ (17.9 mmol, 1.0 equiv) of $N$-BOCpyrrole followed by $10.0 \mathrm{~mL}$ of dry THF. The solution was cooled to $-71{ }^{\circ} \mathrm{C}$ (internal) in a dry ice/acetone bath and a solution of LDA (prepared as described below) was slowly added via cannula over $20 \mathrm{~min}$.

The lithium diisopropylamide (LDA) solution was prepared by placing a solution of 3.14 $\mathrm{mL}$ (22.4 mmol, 1.25 equiv) of dry diisopropylamine in $10.0 \mathrm{~mL}$ of dry THF in a flame-dried, 50-mL two-necked round bottom flask fitted with an argon inlet adapter, magnetic stir bar and septum. The solution was cooled to $-71{ }^{\circ} \mathrm{C}$ in a dry ice/2-propanol bath for $15 \mathrm{~min}$ and $18.67 \mathrm{~mL}$ (1.20 M in hexane, $22.4 \mathrm{mmol}, 1.25$ equiv) of a $n$-BuLi solution was slowly added. The resulting mixture was stirred for $5 \mathrm{~min}$ before being allowed to warm to $0{ }^{0} \mathrm{C}$ (ice bath) slowly. The solution was stirred for $20 \mathrm{~min}$ at $0{ }^{0} \mathrm{C}$ before being cooled to $-70{ }^{0} \mathrm{C}$ and added to the solution prepared above.

The reaction mixture was stirred at $-71{ }^{0} \mathrm{C}$ for $6 \mathrm{~h}$ whereupon $3.26 \mathrm{~mL}$ of $\mathrm{Me}_{2} \mathrm{SiCl}_{2}$ was added. The reaction mixture was allowed to warm to room temperature slowly over a period of $10 \mathrm{~h}$. The reaction mixture was cooled to $0{ }^{\circ} \mathrm{C}$ in an ice bath and $20.0 \mathrm{~mL}$ of sat. aq. $\mathrm{NaHCO}_{3}$ solution was added. The aqueous layer was separated and extracted with EtOAc (4 x $25 \mathrm{~mL})$. The combined organic layers were washed with brine $(1 \times 15 \mathrm{~mL})$ and $\mathrm{H}_{2} \mathrm{O}(1 \mathrm{x} 15 \mathrm{~mL})$ and dried over $\mathrm{MgSO}_{4}$ and filtered through \#4 Whatman filter paper. The solvent was removed under reduced pressure to give an oil which was immediately purified by silica gel chromatography (60 X $100 \mathrm{~mm}$ ) by first eluting with $300 \mathrm{~mL}$ of hexane followed by hexane/EtOAc, 9/1 (30 X $50 \mathrm{~mL}$ fractions) to give a yellow oil which was purified by Kugelrohr distillation to afford $2.183 \mathrm{~g}$ $(50 \%)$ of $\mathbf{4}$ as a clear, colorless semi-solid. 
Data for 4:

bp: $\quad 125{ }^{\circ} \mathrm{C}(0.5 \mathrm{mmHg}, \mathrm{ABT})$

${ }^{1} \underline{\mathrm{H} \text { NMR}}: \quad\left(500 \mathrm{MHz}, \mathrm{CHCl}_{3}\right)$

$7.34(\mathrm{dd}, J=3.0,1.5,1 \mathrm{H}, \mathrm{HC}(5)), 6.51(\mathrm{dd}, J=3.1,1.4,1 \mathrm{H}, \mathrm{HC}(3)), 6.23(\mathrm{t}, J=$ 3.1, $1 \mathrm{H}, \mathrm{HC}(4)), 2.96$ (s, $\left.1 \mathrm{H}, \mathrm{HC}\left(2^{\prime}\right)\right), 1.61$ (s, $9 \mathrm{H}, \mathrm{HC}\left(3^{\prime}\right.$ ')), 0.37 (s, $6 \mathrm{H}$, $\left.\mathrm{HC}\left(1^{\prime}\right)\right)$

${ }^{13}$ C NMR: $\quad\left(125 \mathrm{MHz}, \mathrm{CHCl}_{3}\right)$

150.84 (C(1'’)), 134.28 (C(3)), 124.27 (C(2)), 123.58 (C(5)), 112.24 (C(4)), 84.23 $\left(\mathrm{C}\left(2^{\prime},\right)\right), 27.92\left(\mathrm{C}\left(3^{\prime \prime}\right)\right),-0.13\left(\mathrm{C}\left(1^{\prime}\right)\right)$

IR: (neat)

3373 (s), 2979 (m), 2905 (w), 2826 (w), 2361 (w), 1906 (w), 1841 (w), 1731 (s), 1536 (m), 1478 (w), 1459 (w), 1391 (s), 1370 (w), 1342 (s), 1250 (m), 1207 (w), 1157 (m), 1104 (m), 1057 (w), 1000 (m), 882 (w), 842 (w), 820 (w), 781 (w), 732 (w), $661(\mathrm{w})$

MS: $\quad(\mathrm{EI}, 70 \mathrm{eV})$

$241\left(\mathrm{M}^{+}, 6\right), 185$ (11), 170 (39), 168 (14), 141 (47), 133 (11), 126 (88), 75 (15), 67 (13), 57 (100)

TLC: $\quad R_{f} 0.20$ (hexane/EtOAc, 9/1) [silica gel, UV]

Analysis: $\quad \mathrm{C}_{11} \mathrm{H}_{19} \mathrm{NO}_{3} \mathrm{Si}(241.36)$

Calcd: $\quad$ C, 54.74; H, 7.93; N, 5.80

Found: $\quad$ C, 54.76; H, 8.10; N, 6.15

\section{Preparation of (2-Thienyl)dimethylsilanol (5)}

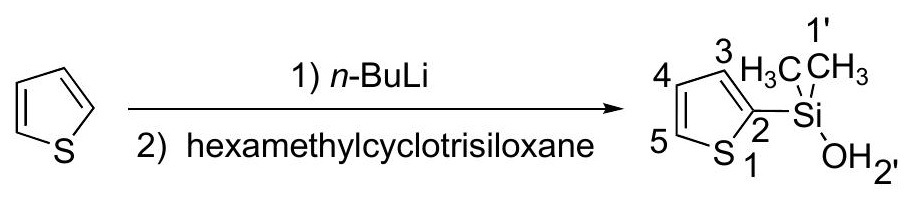

5

To a flame-dried, three-necked, 100-mL round-bottomed flask fitted with an argon inlet adaptor, thermocouple, magnetic stir bar and septum was placed $3.00 \mathrm{~g}$ (35.6 mmol, 1.0 equiv) of thiophene followed by $20.0 \mathrm{~mL}$ of dry diethyl ether. The solution was cooled to $-70{ }^{0} \mathrm{C}$ 
(internal) in a dry ice/acetone bath and $30.9 \mathrm{~mL}$ of $n$-BuLi (1.21 $\mathrm{M}$ in hexane, $37.4 \mathrm{mmol}, 1.05$ equiv) was slowly added. Upon complete addition, the resulting solution was allowed to stir at $70{ }^{\circ} \mathrm{C}$ for $5 \mathrm{~min}$ before being allowed to warm to room temperature and stir for $2 \mathrm{~h}$. The resulting cloudy solution was cooled to $-71{ }^{\circ} \mathrm{C}$ and $2.612 \mathrm{~g}$ (11.75 mmol, 0.33 equiv) of hexamethylcyclotrisiloxane was added. The resulting solution was allowed to warm to room temperature and stir for a period of $16 \mathrm{~h}$ whereupon the mixture was cooled to $0{ }^{0} \mathrm{C}$ and $35.0 \mathrm{~mL}$ of $1.0 \mathrm{M}$ sodium acetate buffer $\mathrm{pH}=5.0$ was added. The aqueous layer was separated and extracted with EtOAc $(3 \times 25 \mathrm{~mL})$. The combined organic layers were washed with brine $(20$ $\mathrm{mL})$, water $(15 \mathrm{~mL})$ and dried over $\mathrm{MgSO}_{4}$ and filtered through \#4 Whatman filter paper. The solvent was removed under reduced pressure to give a red oil which was immediately purified by silica gel chromatography $(60$ X $100 \mathrm{~mm})$ by first eluting with $300 \mathrm{~mL}$ of hexane followed by hexane/EtOAc, 9/1 (30 X $50 \mathrm{~mL}$ fractions). The combined fractions gave a light yellow oil that was distilled to afford $4.049 \mathrm{~g}(72 \%)$ of $\mathbf{5}$ as a clear, colorless oil. The physical and spectroscopic data matched those from the literature. ${ }^{4}$

Data for 5:

bp: $\quad 95{ }^{\circ} \mathrm{C}(0.5 \mathrm{mmHg}, \mathrm{ABT})$

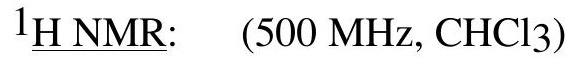

$7.64(\mathrm{~d}, J=4.5,1 \mathrm{H}, \mathrm{HC}(5)), 7.36$ (d, $J=3.3,1 \mathrm{H}, \mathrm{HC}(3)), 7.22$ (dd, $J=4.5,3.3$, $1 \mathrm{H}, \mathrm{HC}(4)), 3.11$ (s, $1 \mathrm{H}, \mathrm{HC}\left(2^{\prime}\right.$ ') )), 0.45 (s, $\left.6 \mathrm{H}, \mathrm{HC}\left(1^{\prime}\right)\right)$

${ }^{13}$ C NMR: $\quad\left(100 \mathrm{MHz}, \mathrm{CHCl}_{3}\right)$

138.50 (C(4)), 134.64 (C(3)), 130.98 (C(5)), 128.11 (C(2)), $0.82\left(\mathrm{C}\left(1^{\prime}\right)\right)$

TLC: $\quad R_{f} 0.25$ (hexane/EtOAc, 4/1) [silica gel, UV]

\section{Preparation of (2-furyl)dimethylsilanol (6)}

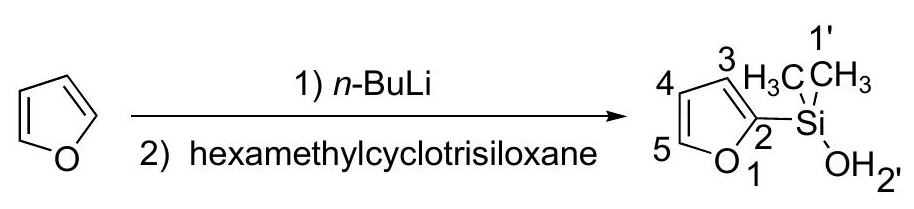

6

To a flame-dried, three-necked, $100 \mathrm{~mL}$ round-bottomed flask fitted with an argon inlet adaptor, thermocouple, magnetic stir bar and septum was placed $10.00 \mathrm{~g}$ (147 mmol, 1.0 equiv) of furan followed by $15.0 \mathrm{~mL}$ of dry diethylether. The solution was cooled to $-71{ }^{\circ} \mathrm{C}$ (internal) in 
a dry ice/acetone bath and $128.5 \mathrm{~mL}$ of $n$-BuLi (1.20 M in hexane, $154 \mathrm{mmol}, 1.05$ equiv) was slowly added. Upon complete addition, the resulting solution was allowed to stir at $-71{ }^{0} \mathrm{C}$ for 5 min before being allowed to warm to room temperature and stir for $4 \mathrm{~h}$. The resulting cloudy solution was cooled to $-71{ }^{0} \mathrm{C}$ and $10.792 \mathrm{~g} \quad(48.5 \mathrm{mmol}, \quad 0.33$ equiv $)$ of hexamethylcyclotrisiloxane was added. The resulting solution was allowed to warm to room temperature and stir for a period of $16 \mathrm{~h}$ whereupon the mixture was cooled to $0{ }^{\circ} \mathrm{C}$ and 100.0 $\mathrm{mL}$ of $1.0 \mathrm{M}$ sodium acetate buffer $\mathrm{pH}=5.0$ was added. The aqueous layer was separated and extracted with EtOAc $(3 \times 50 \mathrm{~mL})$. The combined organic layers were washed with brine (30 $\mathrm{mL})$, water $(30 \mathrm{~mL})$ and dried over $\mathrm{MgSO}_{4}$ and filtered through \#4 Whatman filter paper. The solvent was removed under reduced pressure to give a yellow oil which was immediately purified by silica gel chromatography $(60$ X $100 \mathrm{~mm})$ by first eluting with $300 \mathrm{~mL}$ of hexane followed by hexane/EtOAc, 9/1 (30 X $50 \mathrm{~mL}$ fractions). The combined fractions gave a light yellow oil that was distilled to afford $4.64 \mathrm{~g}(22 \%)$ of $\mathbf{6}$ as a clear, colorless oil.

\section{Data for 6:}

bp: $\quad 90{ }^{\circ} \mathrm{C}(0.5 \mathrm{mmHg}, \mathrm{ABT})$

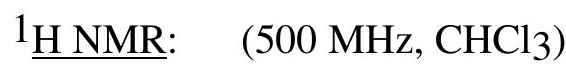

$7.66(\mathrm{~d}, J=1.0,1 \mathrm{H}, \mathrm{HC}(5)), 6.75(\mathrm{~d}, J=3.2,1 \mathrm{H}, \mathrm{HC}(3)), 6.41(\mathrm{dd}, J=3.3,1.6$, $1 \mathrm{H}, \mathrm{HC}(4)), 1.90$ (s, $\left.1 \mathrm{H}, \mathrm{HC}\left(2^{\prime}\right)\right)$ ), 0.42 (s, $\left.6 \mathrm{H}, \mathrm{HC}\left(1^{\prime}\right)\right)$

${ }^{13}$ C NMR: $\quad\left(100 \mathrm{MHz}, \mathrm{CHCl}_{3}\right)$

$158.69(\mathrm{C}(5)), 146.83(\mathrm{C}(2)), 120.41(\mathrm{C}(3)), 109.40(\mathrm{C}(4)),-0.52\left(\mathrm{C}\left(1^{\prime}\right)\right)$

IR: (neat)

3293 (m), 2963 (m), 2903 (w), 2606 (w), 2359 (w), 1630 (w), $1551(\mathrm{~m}), 1456$

(m), 1404 (w), 1361 (w), 1256 (s), 1204 (m), 1149 (w), 1112 (s), 1070 (w), 1007

(s), $872(\mathrm{~s}), 825(\mathrm{~s}), 786(\mathrm{~s}), 746(\mathrm{~s}), 663(\mathrm{~m})$

MS: $\quad(\mathrm{EI}, 70 \mathrm{eV})$

$142\left(\mathrm{M}^{+}, 20\right), 135$ (12), 133 (32), 127 (100), 109 (11), 99 (11), 75 (19)

TLC: $\quad \operatorname{Rf} 0.26$ (hexane/EtOAc, 4/1) [silica gel, $\mathrm{KMnO}_{4}$ ]

Analysis: $\quad \mathrm{C}_{6} \mathrm{H}_{10} \mathrm{O}_{2} \mathrm{Si}(142.23)$
Calcd:
C, 50.67;
H, $7.09 \%$
Found:
C, 50.35;
$\mathrm{H}, 7.19 \%$ 


\section{Preparation of Sodium Silanolates:}

\section{Preparation of Sodium $N$-BOC(2-indolyl)dimethylsilanolate $\left(\mathrm{Na}^{+} \mathbf{1}^{-}\right)$}

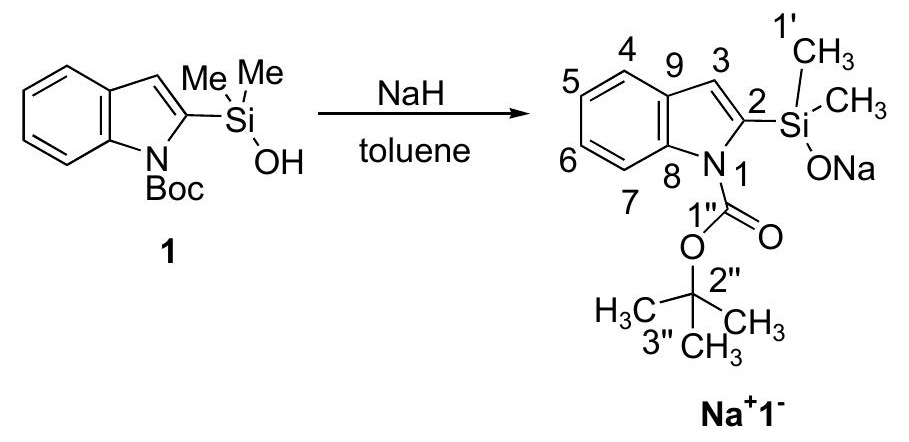

To a flame-dried, 25-mL, conical flask a with stir bar was added $93 \mathrm{mg}$ (3.86 mmol, 1.0 equiv) of $\mathrm{NaH}$ and $2.0 \mathrm{~mL}$ of dry toluene inside a drybox. In a separate flame-dried $5 \mathrm{~mL}$ conical flask was prepared a solution of $1.199 \mathrm{~g}$ (4.1 mmol, 1.06 equiv) of $\mathrm{N}$-BOC(2indolyl)dimethylsilanol in $2.0 \mathrm{~mL}$ of toluene. The silanol solution was added dropwise to the stirred suspension of $\mathrm{NaH}$. The resulting suspension was stirred for $30 \mathrm{~min}$ before allowing the preciptitate to settle. The supernatant was removed carefully with a pipet and the precipitate was washed with $1.0 \mathrm{~mL}$ of toluene, and the supernatant removed. Residual solvent was removed under high vacuum to afford $520 \mathrm{mg}(43 \%)$ of a white powder that was stored in a drybox.

Data for $\mathbf{N a}^{+} \mathbf{1}^{-}$

${ }^{1} \underline{\text { H NMR: }} \quad\left(500 \mathrm{MHz}, \mathrm{C}_{6} \mathrm{D}_{6}\right)$

$7.98(\mathrm{~d}, J=8.3,1 \mathrm{H}, \mathrm{HC}(7)), 7.47$ (d, $J=7.6,1 \mathrm{H}, \mathrm{HC}(4)), 7.26(\mathrm{t}, J=7.7,1 \mathrm{H}$, $\mathrm{HC}(6)), 7.17$ (t, $J=7.6,1 \mathrm{H}, \mathrm{HC}(5)), 6.86$ (s, $1 \mathrm{H}, \mathrm{HC}(3)), 1.31$ (s, $9 \mathrm{H}, \mathrm{HC}\left(3^{\prime}\right.$ ')), 0.49 (s, $\left.6 \mathrm{H}, \mathrm{HC}\left(1^{\prime}\right)\right)$

HRMS: $\quad$ calcd for $\mathrm{C}_{15} \mathrm{H}_{20} \mathrm{NNaO}_{3} \mathrm{Si}\left(\mathrm{M}^{+1}\right)$ : 314.1188 ; found: 314.1183 


\section{Preparation of Sodium (2-thienyl)dimethylsilanolate $\left(\mathrm{Na}^{+} 5\right)$}

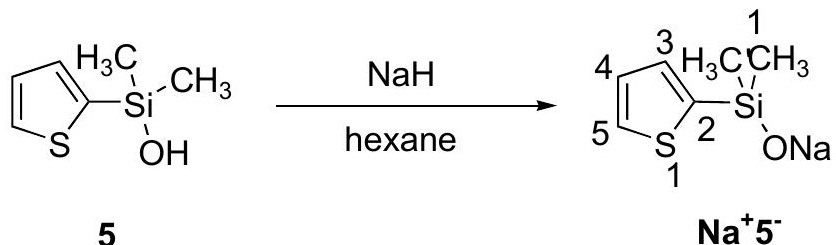

5

$$
\mathrm{Na}^{+} 5^{-}
$$

To a flame-dried, 50-mL conical flask with a stir bar was added $441 \mathrm{mg}(86 \%, 15.8$ mmol, 1.0 equiv) of $\mathrm{NaH}$ and $2.0 \mathrm{~mL}$ of dry hexane inside a drybox. In a separate flame-dried $25 \mathrm{~mL}$ conical flask was prepared a solution of $2.50 \mathrm{~g}$ (15.8 mmol, 1.0 equiv) of (2thienyl)dimethylsilanol in $12.0 \mathrm{~mL}$ of hexane. The silanol solution was added dropwise to the stirred suspension of $\mathrm{NaH}$. The flask that contained the silanol was washed with $3.0 \mathrm{~mL}$ of hexane and this rinse was added to the solution. The resulting solution was stirred for $30 \mathrm{~min}$ before the solvent was removed under high vacuum to afford $2.911 \mathrm{~g}$ (102\%) of an off-white wax that was stored in a freezer in a drybox.

Data for $\mathbf{N a}^{+} \mathbf{5}^{-}$:

${ }^{1}$ H NMR: $\quad(500 \mathrm{MHz}, \mathrm{THF})$

7.47 (d, $J=4.5,1 \mathrm{H}, \mathrm{HC}(5)), 7.22$ (d, $J=3.2,1 \mathrm{H}, \mathrm{HC}(3)), 7.06$ (dd, $J=4.5,3.2$, $1 \mathrm{H}, \mathrm{HC}(4)), 0.18$ (s, $\left.6 \mathrm{H}, \mathrm{HC}\left(1^{\prime}\right)\right)$

${ }^{13} \underline{\mathrm{C} N M R}: \quad(125 \mathrm{MHz}, \mathrm{THF})$

$149.56(\mathrm{C}(4)), 132.62$ (C(3)), $128.92(\mathrm{C}(5)), 128.13(\mathrm{C}(2)), 5.56\left(\mathrm{C}\left(1^{\prime}\right)\right)$

Analysis: $\quad \mathrm{C}_{6} \mathrm{H}_{9} \mathrm{NaOSSi}(180.28)$

Calcd: $\quad \mathrm{Na}, 12.75 \%$

Found: $\quad \mathrm{Na}, 13.33 \%$

\section{Preparation of Sodium (2-furyl)dimethylsilanolate $\left(\mathrm{Na}^{+} \mathrm{6}^{-}\right)$}

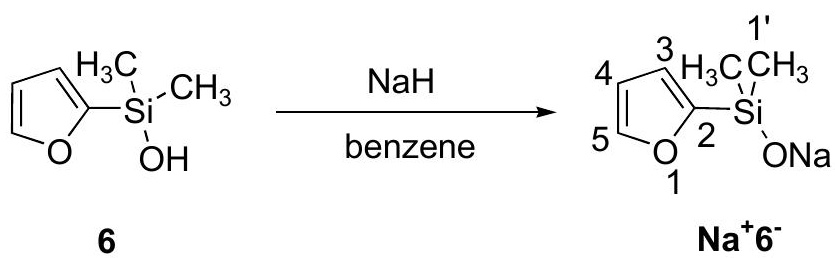

To a flame-dried, 100-mL, conical flask with stir bar was added $374 \mathrm{mg}$ (98\%, 15.3 
mmol, 1.0 equiv) of $\mathrm{NaH}$ and $2.0 \mathrm{~mL}$ of dry benzene inside a drybox. In a separate flame-dried 25-mL conical flask was prepared a solution of $2.17 \mathrm{~g}$ (15.3 mmol, 1.0 equiv) of (2furyl)dimethylsilanol in $12.0 \mathrm{~mL}$ of benzene. The silanol solution was added dropwise to the stirred suspension of $\mathrm{NaH}$. The flask that contained the silanol was washed with $6.0 \mathrm{~mL}$ of benzene and this rinse was added to the solution. The resulting solution was stirred for $1 \mathrm{~h}$ before the solvent was removed under high vacuum to afford $2.4522 \mathrm{~g}(98 \%)$ of a red wax that was stored in a freezer in a drybox.

Data for $\mathrm{Na}^{+} \mathbf{6}^{-}$:

${ }^{1}$ H NMR: $\quad(500 \mathrm{MHz}, \mathrm{THF})$

7.46 (s, $1 \mathrm{H}, \mathrm{HC}(5)), 6.46$ (d, $J=3.2,1 \mathrm{H}, \mathrm{HC}(3)), 6.25(\mathrm{dd}, J=2.9,1.61 \mathrm{H}$, $\mathrm{HC}(4)), 0.07$ (s, $\left.6 \mathrm{H}, \mathrm{HC}\left(1^{\prime}\right)\right)$

${ }^{13}$ C NMR: $\quad(125 \mathrm{MHz}, \mathrm{THF})$

$168.50(\mathrm{C}(5)), 145.26(\mathrm{C}(2)), 117.04(\mathrm{C}(3)), 109.52(\mathrm{C}(4)), 4.22\left(\mathrm{C}\left(1^{\prime}\right)\right)$

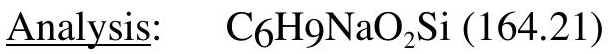

Calcd: $\quad \mathrm{Na}, 14.00 \%$;

Found: $\quad \mathrm{Na}, 13.44 \%$;

General Procedure I: Cross-Coupling Reactions of in situ prepared $\mathrm{Na}^{+} 1^{-}$or $\mathrm{Na}^{+} 4^{-}$or $\mathrm{Na}^{+} 5^{-}$ or $\mathrm{Na}^{+} 6^{-}$with Various Aryl Iodides:

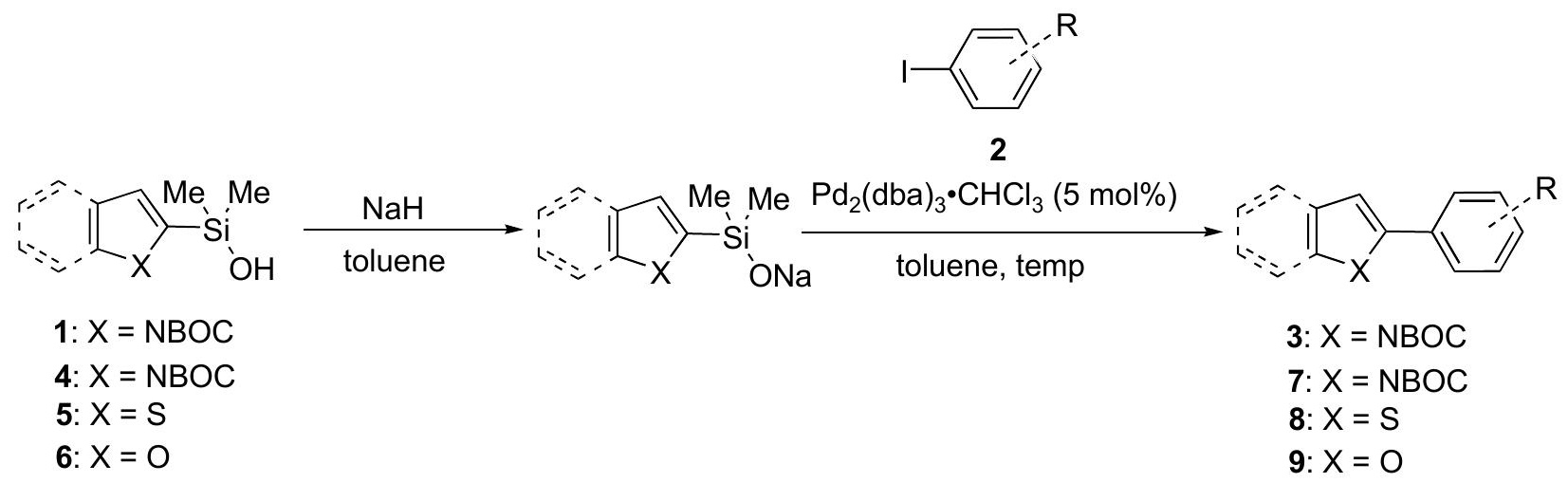

To a flame-dried, 5-mL, round-bottomed flask equipped with a stir bar was added $29 \mathrm{mg}$ (1.2 mmol, 1.2 equiv) of sodium hydride and $0.2 \mathrm{~mL}$ of dry toluene under dry argon atmosphere inside a dry box. In a separate flame-dried, 5 -mL conical flask was added $1.2 \mathrm{mmol}$ of silanol 
(1.2 equiv) which was dissolved in $0.4 \mathrm{~mL}$ of dry toluene and this silanol solution was added dropwise to the $\mathrm{NaH}$ suspension by glass pipet. The round-bottomed flask containing the silanol was washed with $0.4 \mathrm{~mL}$ of dry degassed toluene and that rinse was added to the reaction mixture. The resulting mixture was stirred for $10 \mathrm{~min}$ before $1.0 \mathrm{mmol}$ of aryl iodide, and $52 \mathrm{mg}$ (0.05 mmol, 0.05 equiv) of $\mathrm{Pd}_{2}(\mathrm{dba})_{3} \cdot \mathrm{CHCl}_{3}$ were added. The flask was sealed with a rubber septum and removed from the drybox.

After being stirred at the given temperature for the time specified, the crude reaction mixture was diluted with $25 \mathrm{~mL}$ of deionized $\mathrm{H}_{2} \mathrm{O}$, and $20 \mathrm{~mL}$ of EtOAc. The organic layer was separated, and the aqueous layer was washed with EtOAc (5 X $25 \mathrm{~mL})$. The combined organic layers were dried over $\mathrm{MgSO}_{4}$ and were filtered through \#4 Whatman filter paper. The solvent was removed under reduced pressure to give a dark red residue. A solution of the residue in 0.5 $\mathrm{mL}$ of toluene was loaded onto a silica gel column (20 X $100 \mathrm{~mm})$ which was eluted with toluene (20 X $10 \mathrm{~mL}$ fractions), or eluted with $150 \mathrm{~mL}$ of hexane followed by hexane/EtOAc, 9/1 (20 X $10 \mathrm{~mL}$ fractions). Evaporation of the solvent and purification by recrystallization or sublimation provided the products.

\section{General Procedure II: Cross-Coupling Reactions of in situ prepared $\mathrm{Na}^{+} 5^{-}$or $\mathrm{Na}^{+} 6$ with with Various Aryl Bromides:}

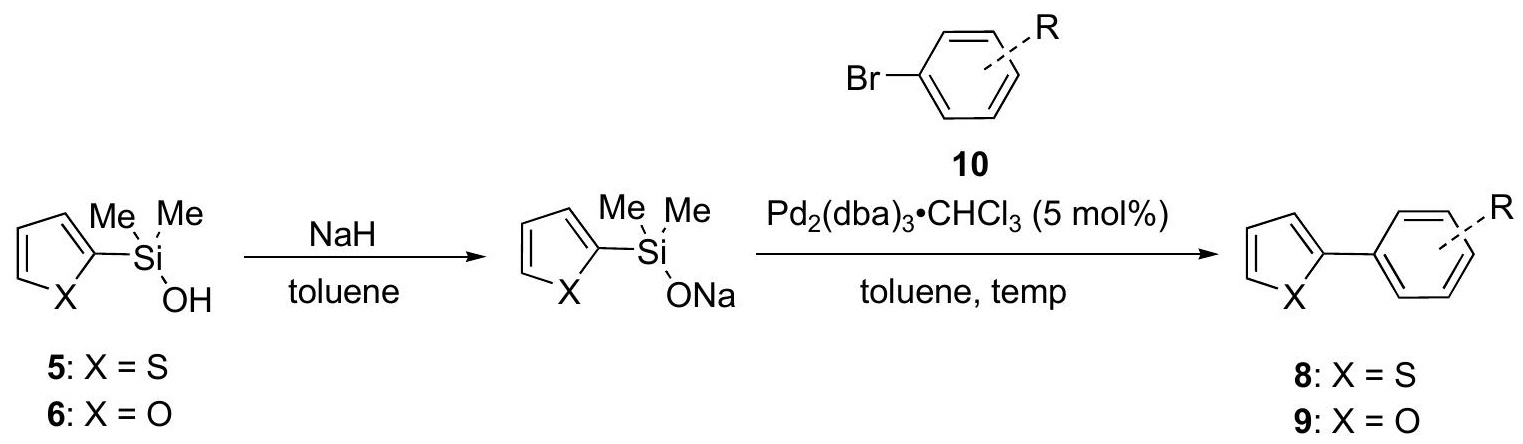

To a flame-dried, 5-mL, round-bottomed flask equipped with a stir bar was added $29 \mathrm{mg}$ (1.2 mmol, 1.2 equiv) of sodium hydride and $0.2 \mathrm{~mL}$ of dry toluene under dry argon atmosphere inside a dry box. In a separate flame-dried 5-mL, conical flask was added $1.2 \mathrm{mmol}$ of silanol (1.2 equiv) which was dissolved in $0.4 \mathrm{~mL}$ of dry toluene and this silanol solution was added dropwise to the above suspension by glass pipet. The round-bottomed flask containing the silanol was washed with $0.4 \mathrm{~mL}$ of dry degassed toluene and that rinse was added to the reaction 
mixture. The resulting mixture was stirred for $10 \mathrm{~min}$ before $1.0 \mathrm{mmol}$ of aryl bromide, and 18 $\mathrm{mg}(0.025 \mathrm{mmol}, 0.025$ equiv) of $\mathbf{1 2}$ were added. The flask was sealed with a rubber septum and removed from the drybox.

After being stirred at $50{ }^{\circ} \mathrm{C}$ for the time specified, the crude reaction mixture was diluted with $25 \mathrm{~mL}$ of deionized $\mathrm{H}_{2} \mathrm{O}$, and $20 \mathrm{~mL}$ of EtOAc. The organic layer was separated, and the aqueous layer was washed with EtOAc $(5 \times 25 \mathrm{~mL})$. The combined organic layers were dried over $\mathrm{MgSO}_{4}$ and were filtered through \#4 Whatman filter paper. The solvent was removed under reduced pressure to give a dark red residue. A solution of the residue in $0.5 \mathrm{~mL}$ of toluene was loaded onto a silica gel column $(20 \mathrm{X} 100 \mathrm{~mm})$ which was eluted with toluene $(20 \mathrm{X} 10 \mathrm{~mL}$ fractions), or eluted with $150 \mathrm{~mL}$ of hexane followed by hexane/EtOAc, 9/1 (20 X $10 \mathrm{~mL}$ fractions). Evaporation of the solvent and purification by sublimation provided the products.

General Procedure III: Cross-Coupling Reactions of pre-formed $\mathrm{Na}^{+} 1^{-}$or $\mathrm{Na}^{+} 5^{-}$or $\mathrm{Na}^{+} 6$ with 2b:<smiles></smiles>

$\mathrm{Na}^{+}{ }^{-}$

or<smiles>C[Si](C)(O[AlH2])c1cccs1</smiles>

$\mathrm{Na}^{+} 5^{-}$

or<smiles>C[Si](C)(O[AlH2])c1ccco1</smiles>

$\mathrm{Na}^{+} 6^{-}$
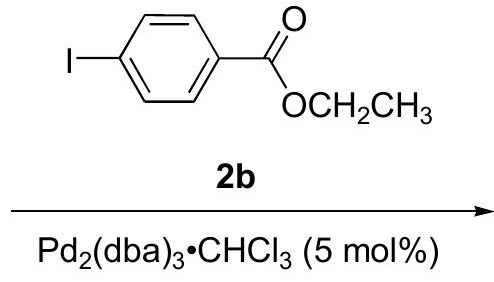

toluene, rt

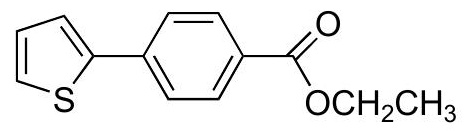

$8 \mathbf{b}$

or

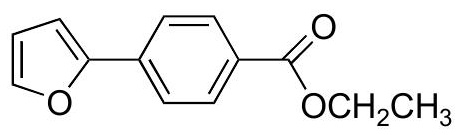

96

To a flame-dried, 5-mL, round-bottomed flask equipped with a stir bar was added 1.2 mmol of sodium silanolate in $1.0 \mathrm{~mL}$ of dry toluene under dry argon atmosphere inside a dry box. To this mixture was added $168 \mu \mathrm{L}$ (1.0 mmol, 1.0 equiv) of ethyl-4-iodobenzoate and 52 
mg (0.05 mmol, 0.05 equiv) of $\mathrm{Pd}_{2}(\mathrm{dba})_{3} \cdot \mathrm{CHCl}_{3}$. The flask was sealed with a rubber septum and removed from the drybox.

After being stirred at $\mathrm{rt}$ for the time specified, the reaction mixture was diluted with 25 $\mathrm{mL}$ of deionized $\mathrm{H}_{2} \mathrm{O}$, and $20 \mathrm{~mL}$ of EtOAc. The organic layer was separated, and the aqueous layer was washed with EtOAc $(5 \times 25 \mathrm{~mL})$. The combined organic layers were dried over $\mathrm{MgSO}_{4}$ and were filtered through \#4 Whatman filter paper. The solvent was removed under reduced pressure to give a dark red residue. A solution of the residue in $0.5 \mathrm{~mL}$ of toluene was loaded onto a silica gel column $(20 \mathrm{X} 100 \mathrm{~mm})$ which was eluted with toluene $(20 \mathrm{X} 10 \mathrm{~mL}$ fractions). Evaporation of the solvent and further purification by recrystallization or sublimation provided the products.

\section{Preparation of 2-(4'-Methoxyphenyl)indole-1-carboxylic Acid tert-Butyl Ester (3a)}

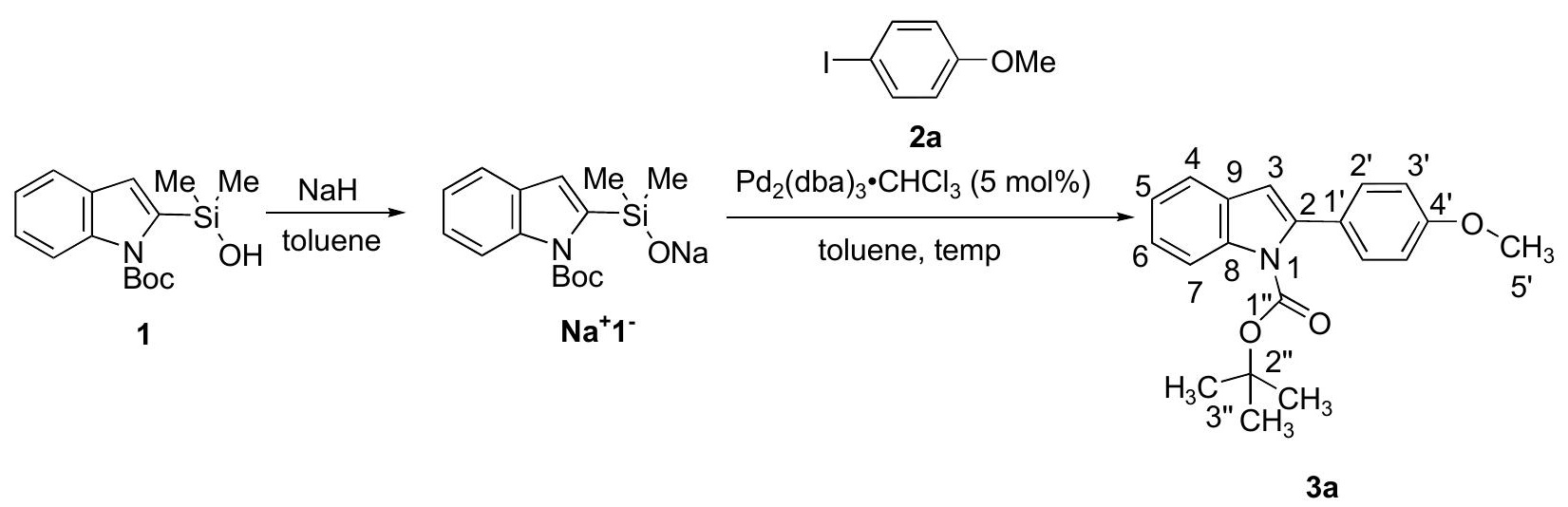

Following General Procedure I, a solution containing $29 \mathrm{mg}$ (1.2 mmol, 1.2 equiv) of $\mathrm{NaH}$, and $349 \mathrm{mg}$ of $\mathrm{N}$-Boc(2-indolyl)dimethylsilanol (1.2 mmol, 1.2 equiv) in $1.0 \mathrm{~mL}$ of toluene in a 5-mL round-bottomed flask under an atmosphere of argon was prepared. To this mixture was added $234 \mathrm{mg}(1.0 \mathrm{mmol})$ of 1-iodo-4-methoxybenzene, and $52 \mathrm{mg}(0.05 \mathrm{mmol}$, 0.05 equiv) of $\mathrm{Pd}_{2}(\mathrm{dba})_{3} \cdot \mathrm{CHCl}_{3}$ whereupon the mixture was stirred at $80{ }^{\circ} \mathrm{C}$ for $3 \mathrm{~h}$, diluted with $25 \mathrm{~mL}$ of deionized $\mathrm{H}_{2} \mathrm{O}$, and $20 \mathrm{~mL}$ of EtOAc. The organic layer was separated, and the aqueous layer was washed with EtOAc (5 X $25 \mathrm{~mL})$. Purification by column chromatography $\left(\mathrm{SiO}_{2}(20 \mathrm{~mm}\right.$ X $100 \mathrm{~mm})$, toluene) and recrystallization (hexane) gave $220 \mathrm{mg}(68 \%)$ of 3a as a white solid. The physical and spectroscopic data matched those from the literature. ${ }^{3}$

Data for 3a:

mp: $\quad 85-87{ }^{\circ} \mathrm{C}$ (hexane) 
$1_{\text {H NMR: }} \quad\left(500 \mathrm{MHz}, \mathrm{CHCl}_{3}\right)$

$8.18(\mathrm{~d}, J=8.3,1 \mathrm{H}, \mathrm{HC}(7)), 7.54(\mathrm{~d}, J=7.1,1 \mathrm{H}, \mathrm{HC}(4)), 7.35(\mathrm{~d}, J=8.8,2 \mathrm{H}$, $\left.\mathrm{HC}\left(2^{\prime}\right)\right), 7.31$ (t, $\left.J=8.5,1 \mathrm{H}, \mathrm{HC}(6)\right), 7.24(\mathrm{t}, J=7.5,1 \mathrm{H}, \mathrm{HC}(5)), 6.94$ (d, $J=$ 8.8, 2 H, HC(3')), 6.51 (s, $1 \mathrm{H}, \mathrm{HC}(3)), 3.86$ (s, $\left.3 \mathrm{H}, \mathrm{HC}\left(5^{\prime}\right)\right), 1.36$ (s, $9 \mathrm{H}$, $\mathrm{HC}(\mathrm{X}))$

${ }^{13}$ C NMR: $\quad\left(125 \mathrm{MHz}, \mathrm{CHCl}_{3}\right)$

$159.21\left(\mathrm{C}\left(1^{\prime} ’\right)\right), 150.26\left(\mathrm{C}\left(4^{\prime}\right)\right), 140.36(\mathrm{C}(8)), 137.26\left(\mathrm{C}\left(1^{\prime}\right)\right), 129.84(\mathrm{C}(9))$, $129.24\left(\mathrm{C}\left(2^{\prime}\right)\right), 127.33(\mathrm{C}(2)), 124.00(\mathrm{C}(5)), 122.81$ (C(4)), $120.24(\mathrm{C}(6))$, $115.14\left(\mathrm{C}\left(3^{\prime}\right)\right), 113.20(\mathrm{C}(7)), 109.43(\mathrm{C}(3)), 83.25$ (C(2’’)), 55.27 (C(5')), 27.59 $\left(\mathrm{C}\left(3^{\prime \prime}\right)\right)$

TLC: $\quad R_{f} 0.33$ (hexane/EtOAc, 9/1) [silica gel, UV]

\section{Preparation of 2-(4'-Ethoxycarbonylphenyl)indole-1-carboxylic Acid tert-Butyl Ester (3b)}

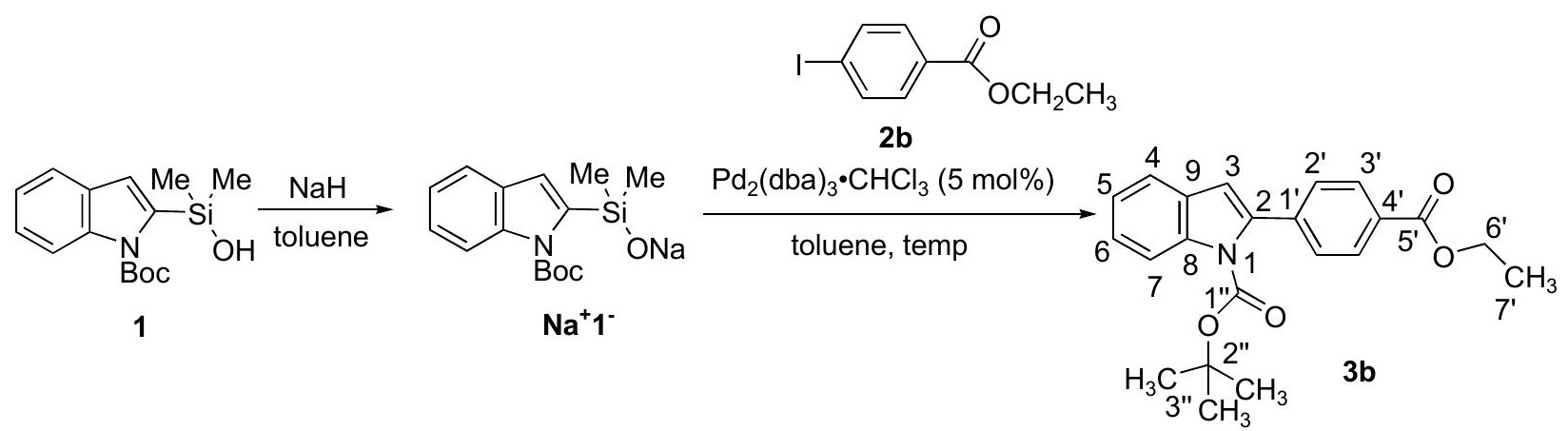

Following General Procedure I, a solution containing $29 \mathrm{mg}$ (1.2 mmol, 1.2 equiv) of $\mathrm{NaH}$, and $349 \mathrm{mg}$ of $N$-Boc(2-indolyl)dimethylsilanol (1.2 mmol, 1.2 equiv) in $1.0 \mathrm{~mL}$ of toluene in a 5-mL round-bottomed flask under an atmosphere of argon was prepared. To this mixture was added $276 \mathrm{mg}(1.0 \mathrm{mmol})$ of ethyl-4-iodobenzoate, and $52 \mathrm{mg}(0.05 \mathrm{mmol}, 0.05$ equiv) of $\mathrm{Pd}_{2}(\mathrm{dba})_{3} \cdot \mathrm{CHCl}_{3}$ whereupon the mixture was stirred at $\mathrm{rt}$ for $3 \mathrm{~h}$, diluted with $25 \mathrm{~mL}$ of deionized $\mathrm{H}_{2} \mathrm{O}$, and $20 \mathrm{~mL}$ of EtOAc. The organic layer was separated, and the aqueous layer was washed with EtOAc $(5 \mathrm{X} 25 \mathrm{~mL})$. Purification by column chromatography $\left(\mathrm{SiO}_{2}(20 \mathrm{~mm} \mathrm{X}\right.$ $100 \mathrm{~mm})$, toluene) and recrystallization from boiling hexane/ toluene (20/1) gave $298 \mathrm{mg}(82 \%)$ of $\mathbf{3 b}$ as a white solid. The physical and spectroscopic data matched those from the literature. ${ }^{5}$ 
Data for 3b:

mp: $\quad 104-105{ }^{\circ} \mathrm{C}$ (hexane/ toluene (20/1))

1슬 $\quad\left(500 \mathrm{MHz}, \mathrm{CHCl}_{3}\right)$

8.21 (d, $J=8.3,1 \mathrm{H}, \mathrm{HC}(7)), 8.09$ (d, $\left.J=8.5,2 \mathrm{H}, \mathrm{HC}\left(3^{\prime}\right)\right), 7.57$ (d, $J=7.3,1 \mathrm{H}$, $\mathrm{HC}(4)), 7.50$ (d, $\left.J=8.5,2 \mathrm{H}, \mathrm{HC}\left(2^{\prime}\right)\right), 7.35$ (t, $\left.J=8.4,1 \mathrm{H}, \mathrm{HC}(6)\right), 7.26$ (t, $J=$ 8.1, $1 \mathrm{H}, \mathrm{HC}(5)), 6.63$ (s, $1 \mathrm{H}, \mathrm{HC}(3)), 4.41$ (q, $\left.J=7.1,2 \mathrm{H}, \mathrm{HC}\left(6^{\prime}\right)\right), 1.42$ (t, $J=$ 7.2, $\left.3 \mathrm{H}, \mathrm{HC}\left(7^{\prime}\right)\right), 1.34$ (s, $\left.9 \mathrm{H}, \mathrm{HC}\left(3^{\prime \prime}\right)\right)$

${ }^{13}$ C NMR: $\quad\left(125 \mathrm{MHz}, \mathrm{CHCl}_{3}\right)$

165.52 (C(5’)), $150.03\left(\mathrm{C}\left(1^{\prime \prime}\right)\right), 139.54\left(\mathrm{C}\left(1^{\prime}\right)\right), 138.87(\mathrm{C}(8)), 137.60\left(\mathrm{C}\left(4^{\prime}\right)\right)$, $130.91\left(\mathrm{C}\left(3^{\prime}\right)\right), 129.08$ (C(9)), $128.93\left(\mathrm{C}\left(2^{\prime}\right)\right), 128.35$ (C(2)), $124.72(\mathrm{C}(5))$, 123.08 (C(4)), 120.67 (C(6)), 115.25 (C(7)), 110.87 (C(3)), 83.87 (C(6’)), 81.08 $\left(\mathrm{C}\left(2^{\prime},\right)\right), 28.17\left(\mathrm{C}\left(7^{\prime}\right)\right), 27.62\left(\mathrm{C}\left(3^{\prime \prime}\right)\right)$

TLC: $\quad R_{f} 0.12$ (hexane/EtOAc, 9/1) [silica gel, UV]

\section{Preparation of 2-(4'-Cyanophenyl)indole-1-carboxylic Acid tert-Butyl Ester (3c)}

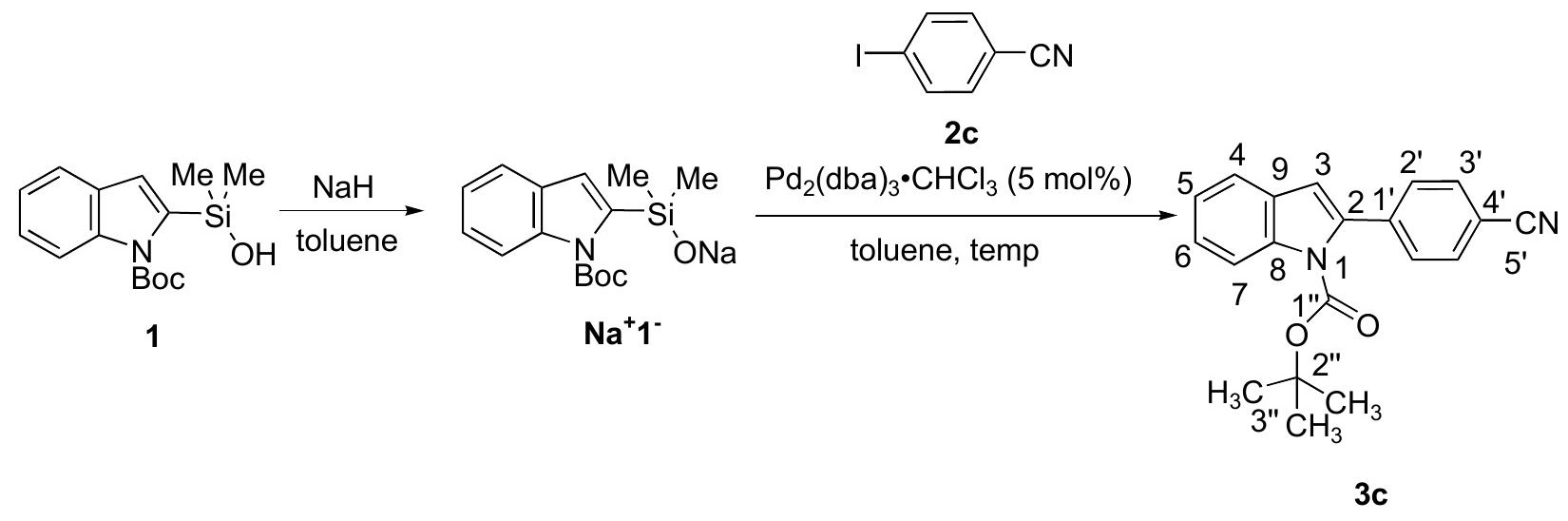

Following General Procedure I, a solution containing $29 \mathrm{mg}$ (1.2 mmol, 1.2 equiv) of $\mathrm{NaH}$, and $349 \mathrm{mg}$ of $\mathrm{N}$-Boc(2-indolyl)dimethylsilanol (1.2 mmol, 1.2 equiv) in $1.0 \mathrm{~mL}$ of toluene in a 5-mL round-bottomed flask under an atmosphere of argon was prepared. To this mixture was added $229 \mathrm{mg}(1.0 \mathrm{mmol})$ of 1-iodo-4-cyanobenzene, and $52 \mathrm{mg}$ (0.05 mmol, 0.05 equiv) of $\mathrm{Pd}_{2}(\mathrm{dba})_{3} \cdot \mathrm{CHCl}_{3}$ whereupon the mixture was stirred at $\mathrm{rt}$ for $3 \mathrm{~h}$, diluted with $25 \mathrm{~mL}$ of deionized $\mathrm{H}_{2} \mathrm{O}$, and $20 \mathrm{~mL}$ of EtOAc. The organic layer was separated, and the aqueous layer was washed with EtOAc $(5 \mathrm{X} 25 \mathrm{~mL})$. Purification by column chromatography $\left(\mathrm{SiO}_{2}(20 \mathrm{~mm} \mathrm{X}\right.$ 
$100 \mathrm{~mm}$ ), toluene) and recrystallization (toluene) gave $257 \mathrm{mg}(81 \%)$ of $\mathbf{3 c}$ as a white solid. The physical and spectroscopic data matched those from the literature. ${ }^{5}$

Data for 3c:

mp: $\quad 122-123{ }^{\circ} \mathrm{C}$ (toluene)

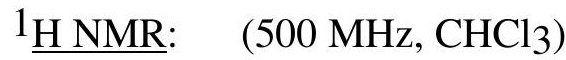

$8.20(\mathrm{~d}, J=8.3,1 \mathrm{H}, \mathrm{HC}(7)), 7.70\left(\mathrm{~d}, J=8.1,2 \mathrm{H}, \mathrm{HC}\left(2^{\prime}\right)\right), 7.58(\mathrm{~d}, J=7.8,1 \mathrm{H}$, $\mathrm{HC}(4)), 7.54$ (d, $\left.J=8.3,2 \mathrm{H}, \mathrm{HC}\left(3^{\prime}\right)\right), 7.38$ (t, $\left.J=8.4,1 \mathrm{H}, \mathrm{HC}(6)\right), 7.28$ (t, $J=$ 7.9, 1 H, HC(5)), 6.64 (s, 1 H, HC(3)), 1.37 (s, 9 H, HC(3'’))

${ }^{13} \underline{\mathrm{C} \mathrm{NMR}}: \quad\left(125 \mathrm{MHz}, \mathrm{CHCl}_{3}\right)$

$149.78\left(\mathrm{C}\left(1^{\prime \prime}\right)\right), 139.42\left(\mathrm{C}\left(1^{\prime}\right)\right), 138.27(\mathrm{C}(8)), 137.64\left(\mathrm{C}\left(3^{\prime}\right)\right), 131.56\left(\mathrm{C}\left(2^{\prime}\right)\right)$, 129.17 (C(9)), 128.86 (C(2)), 125.17 (C(5)), 123.28 (C(6)), 120.87 (C(4)), 118.78 (C(5’)), 115.39 (C(4')), 111.64 (C(7)), 110.98 (C(3)), 84.17 (C(2’’)), 27.60 $\left(\mathrm{C}\left(3^{\prime \prime}\right)\right)$

TLC: $\quad R_{f} 0.24$ (hexane/EtOAc, 9/1) [silica gel, UV]

\section{Preparation of 2-(4'-Methoxyphenyl)pyrrole-1-carboxylic Acid tert-Butyl Ester (7a)}

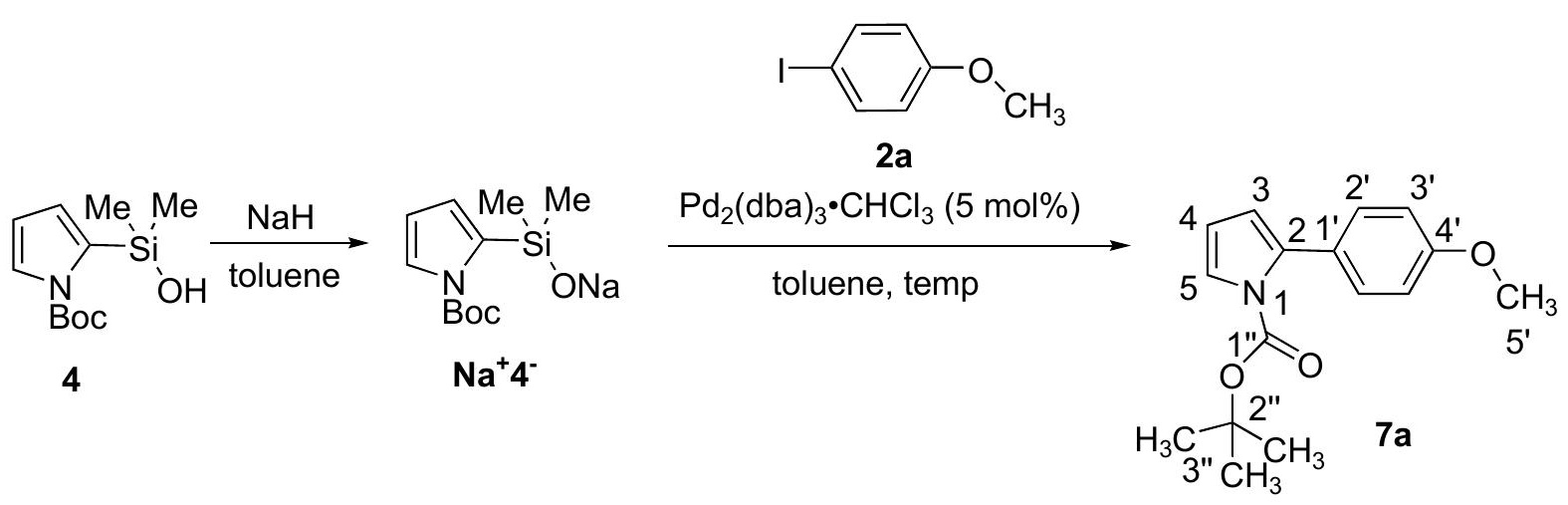

Following General Procedure I, a solution containing $29 \mathrm{mg}$ (1.2 mmol, 1.2 equiv) of $\mathrm{NaH}$, and $290 \mathrm{mg}$ of $\mathrm{N}$-Boc(2-pyrrolyl)dimethylsilanol (1.2 mmol, 1.2 equiv) in $1.0 \mathrm{~mL}$ of toluene in a 5-mL round-bottomed flask under an atmosphere of argon was prepared. To this mixture was added $234 \mathrm{mg}$ (1.0 mmol) of 1-iodo-4-methoxybenzene, and $52 \mathrm{mg}(0.05 \mathrm{mmol}$, 0.05 equiv) of $\mathrm{Pd}_{2}(\mathrm{dba})_{3} \cdot \mathrm{CHCl}_{3}$ whereupon the mixture was stirred at $50{ }^{\circ} \mathrm{C}$ for $36 \mathrm{~h}$, diluted with $25 \mathrm{~mL}$ of deionized $\mathrm{H}_{2} \mathrm{O}$, and $20 \mathrm{~mL}$ of EtOAc. The organic layer was separated, and the aqueous layer was washed with EtOAc (5 X $25 \mathrm{~mL})$. Purification by column chromatography 
$\left(\mathrm{SiO}_{2}(20 \mathrm{~mm}\right.$ X $100 \mathrm{~mm})$, hexane/EtOAc, 9/1) afforded $196 \mathrm{mg}(72 \%)$ of 7a as a white semisolid. The physical and spectroscopic data matched those from the literature. ${ }^{6}$

Data for 7a:

1ㅁN

$7.32(\mathrm{dd}, J=3.3,1.8,1 \mathrm{H}, \mathrm{HC}(5)), 7.27$ (d, $\left.J=8.8,2 \mathrm{H}, \mathrm{HC}\left(2^{\prime}\right)\right), 6.89$ (d, $J=8.6$, $\left.2 \mathrm{H}, \mathrm{HC}\left(3^{\prime}\right)\right), 6.21$ (t, $\left.J=3.3,1 \mathrm{H}, \mathrm{HC}(4)\right), 6.13$ (dd, $\left.J=3.2,1.7,1 \mathrm{H}, \mathrm{HC}(3)\right)$, 3.83 (s, $\left.3 \mathrm{H}, \mathrm{HC}\left(5^{\prime}\right)\right)$ ), 1.387 (s, $9 \mathrm{H}, \mathrm{HC}\left(3^{\prime}\right.$ '))

${ }^{13}$ C NMR: $\quad\left(125 \mathrm{MHz}, \mathrm{CHCl}_{3}\right)$

158.87 (C(4')), 149.39 (C(1’’)), 134.85 (C(2’)), 130.38 (C(1')), $126.85(\mathrm{C}(2))$, 122.14 (C(5)), $113.97\left(\mathrm{C}\left(3^{\prime}\right)\right), 113.00$ (C(3)), 110.44 (C(4)), 83.39 (C(2’’)), 55.23 $\left(\mathrm{C}\left(5^{\prime}\right)\right), 27.65\left(\mathrm{C}\left(3^{\prime},\right)\right)$

TLC: $\quad R_{f} 0.28$ (hexane/EtOAc, 9/1) [silica gel, UV]

\section{Preparation of 2-(4'-Ethoxycarbonylphenyl)pyrrole-1-carboxylic Acid tert-Butyl Ester (7b)}

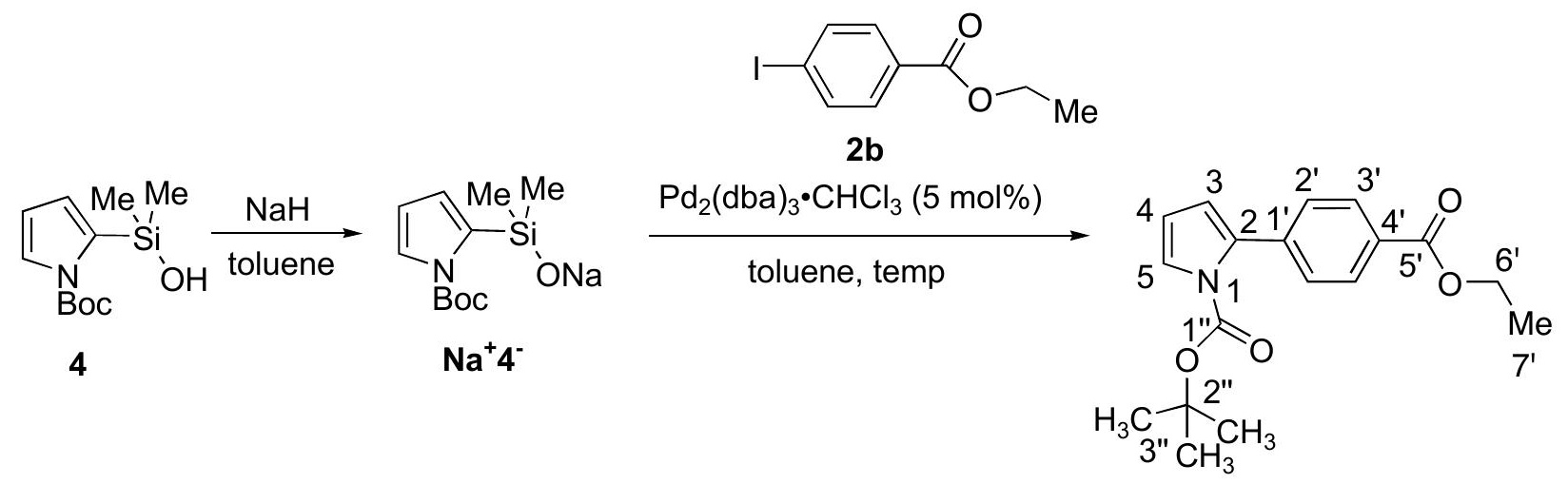

$7 \mathbf{b}$

Following General Procedure I, a solution containing $29 \mathrm{mg}$ (1.2 mmol, 1.2 equiv) of $\mathrm{NaH}$, and $290 \mathrm{mg}$ of $\mathrm{N}$-Boc(2-pyrrolyl)dimethylsilanol (4) (1.2 mmol, 1.2 equiv) in $1.0 \mathrm{~mL}$ of toluene in a 5-mL round-bottomed flask under an atmosphere of argon was prepared. To this mixture was added $168 \mu \mathrm{L}(1.0 \mathrm{mmol})$ of ethyl 4-iodobenzoate $(\mathbf{2 b})$, and $52 \mathrm{mg}(0.05 \mathrm{mmol}$, 0.05 equiv) of $\operatorname{Pd}_{2}(\mathrm{dba})_{3} \cdot \mathrm{CHCl}_{3}$ whereupon the mixture was stirred at $\mathrm{rt}$ for $3 \mathrm{~h}$, diluted with 25 $\mathrm{mL}$ of deionized $\mathrm{H}_{2} \mathrm{O}$, and $20 \mathrm{~mL}$ of EtOAc. The organic layer was separated, and the aqueous 
layer was washed with EtOAc $(5$ X $25 \mathrm{~mL})$. Purification by column chromatography $\left(\mathrm{SiO}_{2}(20\right.$ mm X $100 \mathrm{~mm})$, toluene), afforded $239 \mathrm{mg}$ (76\%) of $\mathbf{7 b}$ as a clear semi-solid for which correct microanalytical data could not be obtained.

Data for 7b:

1ㅁN $\underline{\text { NMR: }} \quad\left(500 \mathrm{MHz}, \mathrm{CHCl}_{3}\right)$

$8.03(\mathrm{dd}, J=6.7,1.8,2$ H, HC(3')), 7.42 (dd, $J=6.6,1.7,2$ H, HC(2')), 7.38 (dd, $J=3.2,2.0,1 \mathrm{H}, \mathrm{HC}(5)), 6.25$ (m, $2 \mathrm{H}, \mathrm{HC}(3), \mathrm{HC}(4)), 4.39$ (q, $J=7.2,2 \mathrm{H}$, $\left.\mathrm{HC}\left(6^{\prime}\right)\right), 1.40$ (t, $\left.J=7.0,3 \mathrm{H}, \mathrm{HC}\left(7^{\prime}\right)\right), 1.38$ (s, 9 H, HC(3'’))

${ }^{13}$ C NMR: $\quad\left(125 \mathrm{MHz}, \mathrm{CHCl}_{3}\right)$

166.47 (C(5')), $149.14\left(\mathrm{C}\left(1^{\prime \prime}\right)\right), 138.75\left(\mathrm{C}\left(1^{\prime}\right)\right), 134.00\left(\mathrm{C}\left(4^{\prime}\right)\right), 128.91(\mathrm{C}(2))$, 128.85 (C(2’)), 128.85 (C(3’)), 123.43 (C(5)), 115.37 (C(3)), 110.80 (C(4)), 84.01 $\left(\mathrm{C}\left(2^{\prime \prime}\right)\right), 60.89\left(\mathrm{C}\left(6^{\prime}\right)\right), 27.63\left(\mathrm{C}\left(3^{\prime \prime}\right)\right), 14.33$ (C(7’))

IR: (neat)

2981 (m), 2936 (w), 1741 (s), 1716 (s), 1611 (m), 1572 (w), 1512 (w), 1466 (m), 1413 (m), 1394 (s), 1369 (s), 1337 (s), 1313 (s), 1273 (s), 1177 (m), 1147 (s), 1101 (s), 1075 (m), 1040 (m), 1021 (m), 974 (m), 881 (w), 861 (m), 849 (m), 818 (w), $774(\mathrm{~m}), 731(\mathrm{~m}), 704(\mathrm{~m}), 667(\mathrm{w})$

MS: $\quad(\mathrm{EI}, 70 \mathrm{eV})$

$316\left(\mathrm{M}^{+1}, 2\right), 315$ (10), 259 (26), 215 (73), 187 (31), 170 (18), 88 (12), 86 (67), $84(100), 57(95)$

TLC: $\quad R_{f} 0.24$ (hexane/EtOAc, 9/1) [silica gel, UV]

HRMS: $\quad$ calcd for $\mathrm{C}_{18} \mathrm{H}_{21} \mathrm{NO}_{4}$ : 315.1471 ; found: 315.1468 


\section{Preparation of 2-(2'-Methylphenyl)pyrrole-1-carboxylic Acid tert-Butyl Ester (7d)}

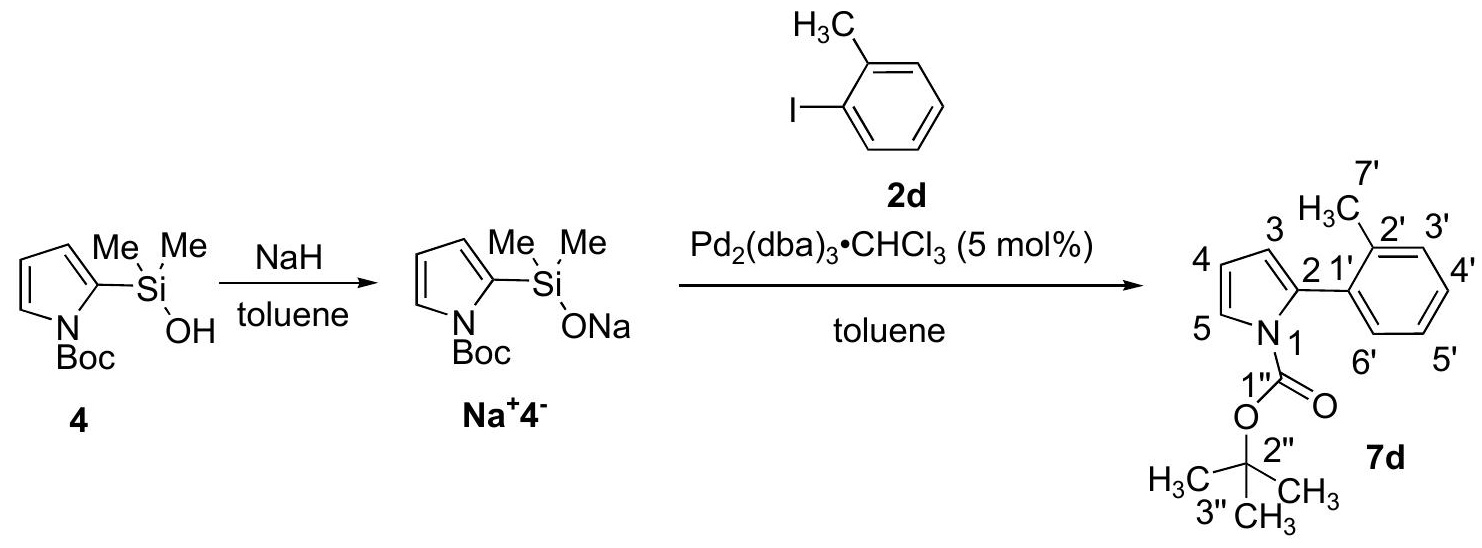

Following General Procedure I, a solution containing $29 \mathrm{mg}$ (1.2 mmol, 1.2 equiv) of $\mathrm{NaH}$, and $290 \mathrm{mg}$ of $\mathrm{N}$-Boc(2-pyrrolyl)dimethylsilanol (1.2 mmol, 1.2 equiv) in $1.0 \mathrm{~mL}$ of toluene in a 5-mL round-bottomed flask under an atmosphere of argon was prepared. To this mixture was added $218 \mathrm{mg}(1.0 \mathrm{mmol})$ of 1-iodo-2-methylbenzene, and $52 \mathrm{mg}(0.05 \mathrm{mmol}, 0.05$ equiv) of $\mathrm{Pd}_{2}(\mathrm{dba})_{3} \cdot \mathrm{CHCl}_{3}$ whereupon the mixture was stirred at rt for $3 \mathrm{~h}$, diluted with $25 \mathrm{~mL}$ of deionized $\mathrm{H}_{2} \mathrm{O}$, and $20 \mathrm{~mL}$ of EtOAc. The organic layer was separated, and the aqueous layer was washed with EtOAc $(5 \mathrm{X} 25 \mathrm{~mL})$. Purification by column chromatography $\left(\mathrm{SiO}_{2}(20 \mathrm{~mm} \mathrm{X}\right.$ $100 \mathrm{~mm})$, hexane/EtOAc (9/1)) afforded $205 \mathrm{mg}(80 \%)$ of 7d as a clear, colorless semi-solid.

\section{Data for 7d:}

1ㅁN $\underline{\text { NMR: }} \quad\left(500 \mathrm{MHz}, \mathrm{CHCl}_{3}\right)$

$7.37(\mathrm{dd}, J=3.4,1.7,1 \mathrm{H}, \mathrm{HC}(5)), 7.21$ (m, $4 \mathrm{H}, \mathrm{HC}\left(3^{\prime}\right), \mathrm{HC}\left(4^{\prime}\right), \mathrm{HC}\left(5^{\prime}\right)$, HC(6’)), 6.25 (t, $J=3.3,1 \mathrm{H}, \mathrm{HC}(4)), 6.08$ (dd, $J=3.2,1.7,1 \mathrm{H}, \mathrm{HC}(3)), 2.12$ (s, $\left.3 \mathrm{H}, \mathrm{HC}\left(7^{\prime}\right)\right), 1.24$ (s, 9 H, HC(3' '))

${ }^{13}$ C NMR: $\quad\left(125 \mathrm{MHz}, \mathrm{CHCl}_{3}\right)$

149.35 (C(1’’)), 137.84 (C(2’)), 134.95 (C(1')), 133.59 (C(3’)), 130.12 (C(4')), 129.22 (C(6’)), 127.81 (C(5')), 125.09 (C(2)), 121.30 (C(5)), 113.65 (C(3)), 110.46 (C(4)), 83.07 (C(2’’)), 27.39 (C(3’’)), 19.85 (C(7’))

IR: (neat)

3461 (w), 3152 (w), 3110 (w), 3062 (w), 2980 (m), 2933 (w), 2645 (w), 1739 (s), 1606 (w), 1444 (w), 1502 (w), 1473 (m), 1458 (m), 1395 (s), 1371 (s), 1340 (s), 
1313 (s), 1258 (m), 1153 (s), 1117 (m), 1074 (m), 1032 (w), 871 (m), 952 (w), $882(\mathrm{w}), 850(\mathrm{~m}), 842(\mathrm{~m}), 816(\mathrm{w}), 796(\mathrm{w}), 773(\mathrm{w}), 762(\mathrm{~m}), 726(\mathrm{~s}), 664(\mathrm{w})$

$\underline{\mathrm{MS}}: \quad(\mathrm{EI}, 70 \mathrm{eV})$

$258\left(\mathrm{M}^{+1}, 6\right), 257$ (27), 201 (47), 184 (15), 158 (12), 157 (90), 156 (37), 129

(11), $128(11), 57(100)$

TLC: $\quad R f 0.44$ (hexane/EtOAc, 9/1) [silica gel, UV]

Analysis: $\quad \mathrm{C}_{16} \mathrm{H}_{19} \mathrm{NO}_{2}(257.33)$

$\begin{array}{llll}\text { Calcd: } & \text { C , 74.68; } & \text { H, 7.44; } & \text { N, 5.44\% } \\ \text { Found: } & \text { C , 74.44; } & \text { H, 7.47; } & \text { N, 5.79\% }\end{array}$

\section{Preparation of 2-(4'-Methoxyphenyl)furan (8a)}

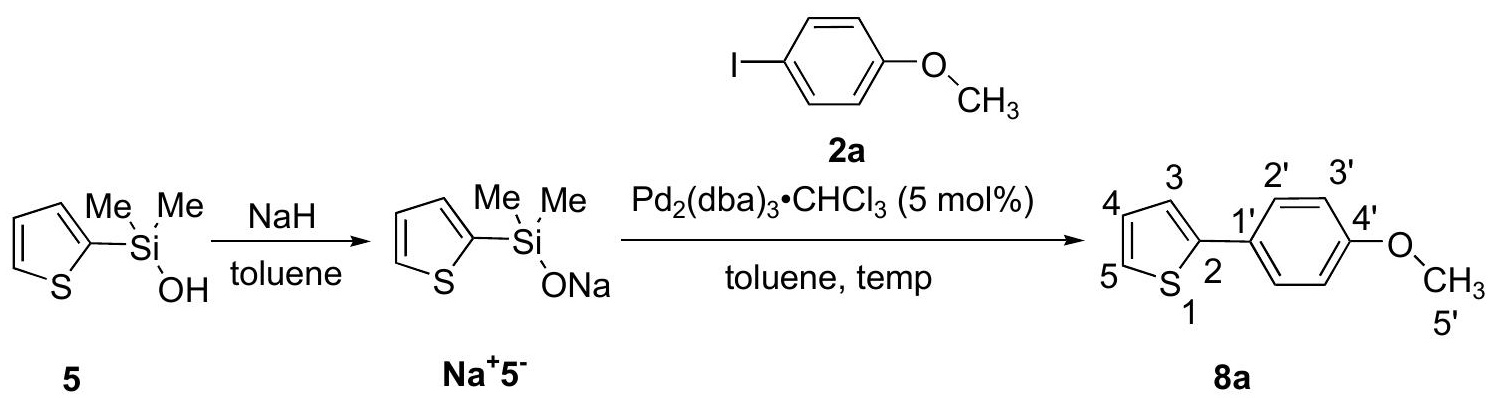

Following General Procedure I, a solution containing $29 \mathrm{mg}$ (1.2 mmol, 1.2 equiv) of $\mathrm{NaH}$, and $190 \mathrm{mg}$ of 2-thienyldimethylsilanol (1.2 mmol, 1.2 equiv) in $1.0 \mathrm{~mL}$ of toluene in a 5$\mathrm{mL}$ round-bottomed flask under an atmosphere of argon was prepared. To this mixture was added $234 \mathrm{mg}$ (1.0 mmol) of 1-iodo-4-methoxybenzene, and $52 \mathrm{mg}$ (0.05 mmol, 0.05 equiv) of $\mathrm{Pd}_{2}(\mathrm{dba})_{3} \cdot \mathrm{CHCl}_{3}$ whereupon the mixture was stirred at $80{ }^{\circ} \mathrm{C}$ for $24 \mathrm{~h}$. The reaction mixture was diluted with $25 \mathrm{~mL}$ of deionized $\mathrm{H}_{2} \mathrm{O}$, and $20 \mathrm{~mL}$ of EtOAc. The organic layer was separated, and the aqueous layer was washed with EtOAc $(5 \mathrm{X} 25 \mathrm{~mL})$. Purification by column chromatography $\left(\mathrm{SiO}_{2}(20 \mathrm{~mm} \times 100 \mathrm{~mm})\right.$, toluene $)$ and sublimation $\left(0.5 \mathrm{mmHg}, 50{ }^{0} \mathrm{C}\right)$ afforded $137 \mathrm{mg}(72 \%)$ of $\mathbf{8 a}$ as a white solid. The physical and spectroscopic data matched those from the literature. ${ }^{7}$

Data for 8a:

mp: $\quad 103-104{ }^{0} \mathrm{C}$ 
${ }^{1} \underline{\mathrm{H} N M R}:\left(500 \mathrm{MHz}, \mathrm{CHCl}_{3}\right)$

$7.55\left(\mathrm{~d}, J=8.8,2 \mathrm{H}, \mathrm{HC}\left(2^{\prime}\right)\right), 7.21$ (m, $\left.2 \mathrm{H}, \mathrm{HC}(5), \mathrm{HC}(3)\right), 7.05$ (dd, $J=5.0,3.5$, $1 \mathrm{H}, \mathrm{HC}(4)), 6.92$ (d, $J=8.8,2$ H, HC(3')), 3.84 (s, 3 H, HC(5'))

${ }^{13} \underline{\mathrm{C} \mathrm{NMR}}: \quad\left(125 \mathrm{MHz}, \mathrm{CHCl}_{3}\right)$

$159.14\left(\mathrm{C}\left(4^{\prime}\right)\right), 144.30(\mathrm{C}(2)), 127.91\left(\mathrm{C}\left(2^{\prime}\right)\right), 127.25$ (C(4)), 127.18 (C(3)), $123.80\left(\mathrm{C}\left(1^{\prime}\right)\right), 122.05(\mathrm{C}(5)), 114.22\left(\mathrm{C}\left(3^{\prime}\right)\right), 55.28\left(\mathrm{C}\left(5^{\prime}\right)\right)$

TLC: $\quad R_{f} 0.47$ (hexane/EtOAc, 9/1) [silica gel, UV]

GC: $\quad t_{R} \mathbf{8 a}, 8.47 \mathrm{~min}(100.0 \%)(\mathrm{HP}-5,15 \mathrm{psi})$

\section{Preparation of 2-(4'-Ethoxycarbonylphenyl)thiophene (8b)}

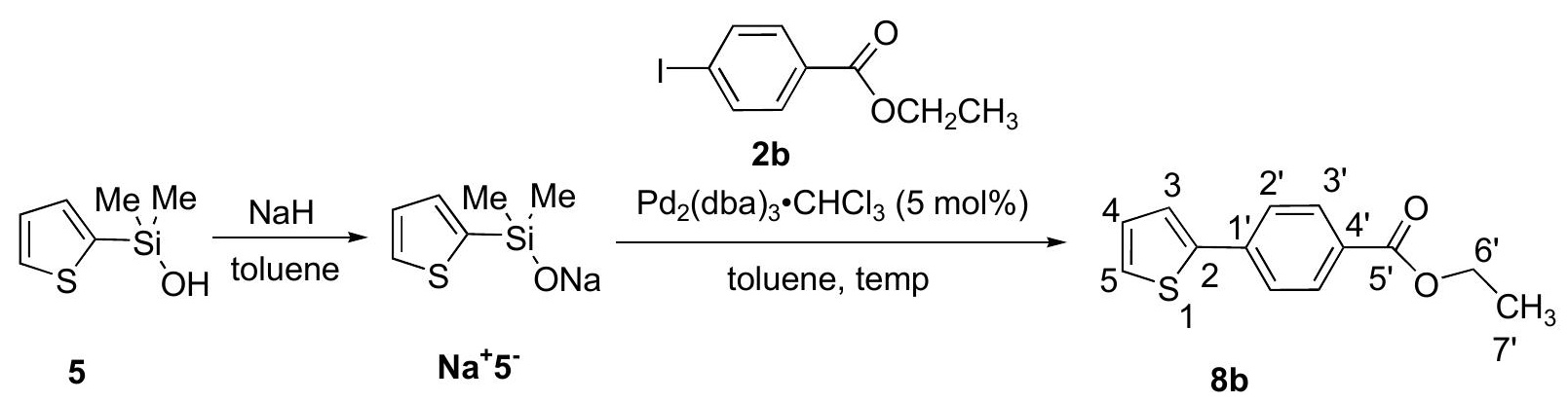

Following General Procedure I, a solution containing $29 \mathrm{mg}$ (1.2 mmol, 1.2 equiv) of $\mathrm{NaH}$, and $190 \mathrm{mg}$ of 2-thienyldimethylsilanol (1.2 mmol, 1.2 equiv) in $1.0 \mathrm{~mL}$ of toluene in a 5$\mathrm{mL}$ round-bottomed flask under an atmosphere of argon was prepared. To this mixture was added $276 \mathrm{mg}(1.0 \mathrm{mmol})$ of ethyl-4-iodobenzoate, and $52 \mathrm{mg}(0.05 \mathrm{mmol}, 0.05$ equiv) of $\mathrm{Pd}_{2}(\mathrm{dba})_{3} \bullet \mathrm{CHCl}_{3}$ and the mixture was stirred at $\mathrm{rt}$ for $3 \mathrm{~h}$. The reaction mixture was diluted with $25 \mathrm{~mL}$ of deionized $\mathrm{H}_{2} \mathrm{O}$, and $20 \mathrm{~mL}$ of EtOAc. The organic layer was separated, and the aqueous layer was washed with EtOAc (5 X $25 \mathrm{~mL})$. Purification by column chromatography $\left(\mathrm{SiO}_{2}(20 \mathrm{~mm})\right.$, toluene $)$ and sublimation $\left(0.5 \mathrm{mmHg}, 50{ }^{\circ} \mathrm{C}\right)$ afforded $180 \mathrm{mg}(78 \%)$ of $\mathbf{8 b}$ as a white solid.

Data for 8b:

mp: $\quad 67-68{ }^{\circ} \mathrm{C}$

1ㅁN NMR: $\quad\left(500 \mathrm{MHz}, \mathrm{CHCl}_{3}\right)$

$8.04\left(\mathrm{~d}, J=8.8,2 \mathrm{H}, \mathrm{HC}\left(3^{\prime}\right)\right), 7.67$ (d, $\left.J=8.8,2 \mathrm{H}, \mathrm{HC}\left(2^{\prime}\right)\right), 7.42$ (dd, $J=3.6$, 
1.3, $1 \mathrm{H}, \mathrm{HC}(5)), 7.36(\mathrm{dd}, J=5.1,1.1,1 \mathrm{H}, \mathrm{HC}(3)), 7.12(\mathrm{dd}, J=4.9,3.6,1 \mathrm{H}$, $\mathrm{HC}(4)), 4.39$ (q, $\left.J=7.1,2 \mathrm{H}, \mathrm{HC}\left(6^{\prime}\right)\right), 1.41$ (t, $\left.J=7.2,3 \mathrm{H}, \mathrm{HC}\left(7^{\prime}\right)\right)$

${ }^{13}$ C NMR: $\quad\left(125 \mathrm{MHz}, \mathrm{CHCl}_{3}\right)$

166.31 (C(5')), $143.13(\mathrm{C}(2)), 138.52$ (C(1')), 130.23 (C(3’)), 129.12 (C(4')), 128.30 (C(4)), 126.23 (C(3)), 125.48 (C(2’)), 124.43 (C(5)), 60.97 (C(6’)), 14.31 $\left(\mathrm{C}\left(7^{\prime}\right)\right)$

IR: (Nujol)

3422 (m), 3088 (w), 3066 (w), 2962 (s), 2871 (m), 1722 (w), 1703 (s), 1604 (m), 1564 (w), 1534 (w), 1462 (w), 1424 (w), 1411 (w), 1391 (w), 1364 (w), 1317 (w), 1277 (s), 1262 (s), 1184 (m), 1169 (w), 1110 (s), 1016 (w), 959 (w), 862 (w), 856 (w), $832(\mathrm{w}), 773(\mathrm{~s}), 727(\mathrm{~s}), 710(\mathrm{w}), 697(\mathrm{w})$

MS: $\quad(E I, 70 \mathrm{eV})$

$232\left(\mathrm{M}^{+}, 80\right), 204$ (28), 187 (100), 159 (17), 115 (37), 93 (8), 79 (10), 62 (5)

TLC: $\quad R f 0.35$ (hexane/EtOAc, 9/1) [silica gel, UV]

GC: $\quad t_{R} \mathbf{8 b}, 10.97 \min (100.0 \%)(\mathrm{HP}-5,15 \mathrm{psi})$

Analysis: $\quad \mathrm{C}_{13} \mathrm{H}_{12} \mathrm{O}_{2} \mathrm{~S}(232.30)$

Calcd: $\quad$ C, 67.21; H, 5.21\%

Found: $\quad$ C, $67.10 ; \quad \mathrm{H}, 5.51 \%$

\section{Preparation of 2-(4'-Cyanophenyl)thiophene (8c)}

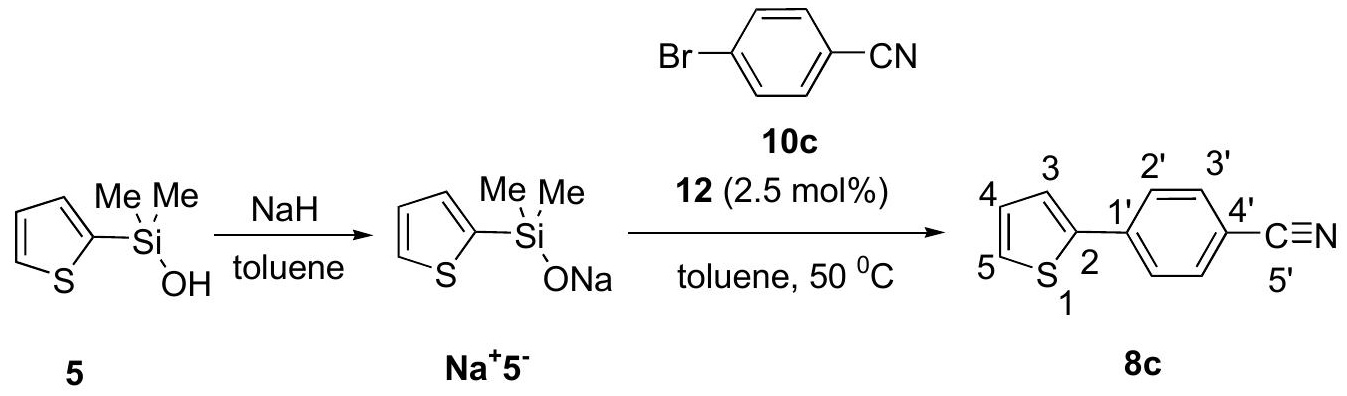

Following General Procedure II, a solution containing $29 \mathrm{mg}$ (1.2 mmol, 1.2 equiv) of $\mathrm{NaH}$, and $190 \mathrm{mg}$ of 2-thienyldimethylsilanol (1.2 mmol, 1.2 equiv) in $1.0 \mathrm{~mL}$ of toluene in a 5$\mathrm{mL}$ round-bottomed flask under an atmosphere of argon was prepared. To this mixture was added $182 \mathrm{mg}$ (1.0 mmol) of 1-bromo-4-cyanobenzene, and $18 \mathrm{mg}(0.025 \mathrm{mmol}, 0.025 \mathrm{equiv})$ of 
12 and the mixture was stirred at $50{ }^{\circ} \mathrm{C}$ for $3 \mathrm{~h}$. The reaction mixture was diluted with $25 \mathrm{~mL}$ of deionized $\mathrm{H}_{2} \mathrm{O}$, and $20 \mathrm{~mL}$ of EtOAc. The organic layer was separated, and the aqueous layer was washed with EtOAc $(5 \mathrm{X} 25 \mathrm{~mL})$. Purification by column chromatography $\left(\mathrm{SiO}_{2}(20 \mathrm{~mm} \mathrm{X}\right.$ $100 \mathrm{~mm})$, toluene) and sublimation $\left(0.5 \mathrm{mmHg}, 50{ }^{\circ} \mathrm{C}\right)$ afforded $144 \mathrm{mg}(78 \%)$ of $8 \mathrm{c}$ as a white solid. The physical and spectroscopic data matched those from the literature. ${ }^{8}$

Data for 8c:

mp: $\quad 91-92{ }^{\circ} \mathrm{C}$

1슬 $: \quad\left(500 \mathrm{MHz}, \mathrm{CHCl}_{3}\right)$

$7.70\left(\mathrm{~d}, J=8.5,2 \mathrm{H}, \mathrm{HC}\left(2^{\prime}\right)\right), 7.66\left(\mathrm{~d}, J=8.8,2 \mathrm{H}, \mathrm{HC}\left(3^{\prime}\right)\right), 7.43$ (dd, $J=3.7$, 1.2, $1 \mathrm{H}, \mathrm{HC}(5)), 7.40(\mathrm{dd}, J=5.1,1.2,1 \mathrm{H}, \mathrm{HC}(3)), 7.13(\mathrm{dd}, J=4.9,3.7,1 \mathrm{H}$, $\mathrm{HC}(4))$

${ }^{13} \mathrm{C} \mathrm{NMR}: \quad\left(125 \mathrm{MHz}, \mathrm{CHCl}_{3}\right)$

$141.94(\mathrm{C}(2)), 138.52$ (C(1')), 132.63 (C(3’)), 128.47 (C(2')), $127.00(\mathrm{C}(4))$, 125.95 (C(3)), $125.04(\mathrm{C}(5)), 118.78$ (C(5’)), 110.34 (C(4'))

TLC: $\quad R_{f} 0.24$ (hexane/EtOAc, 9/1) [silica gel, UV]

GC: $\quad t_{R} \mathbf{8 c}, 9.17 \min (97.3 \%)(\mathrm{HP}-5,15 \mathrm{psi})$

\section{Preparation of 2-(2'-Methylphenyl)thiophene (8d)}

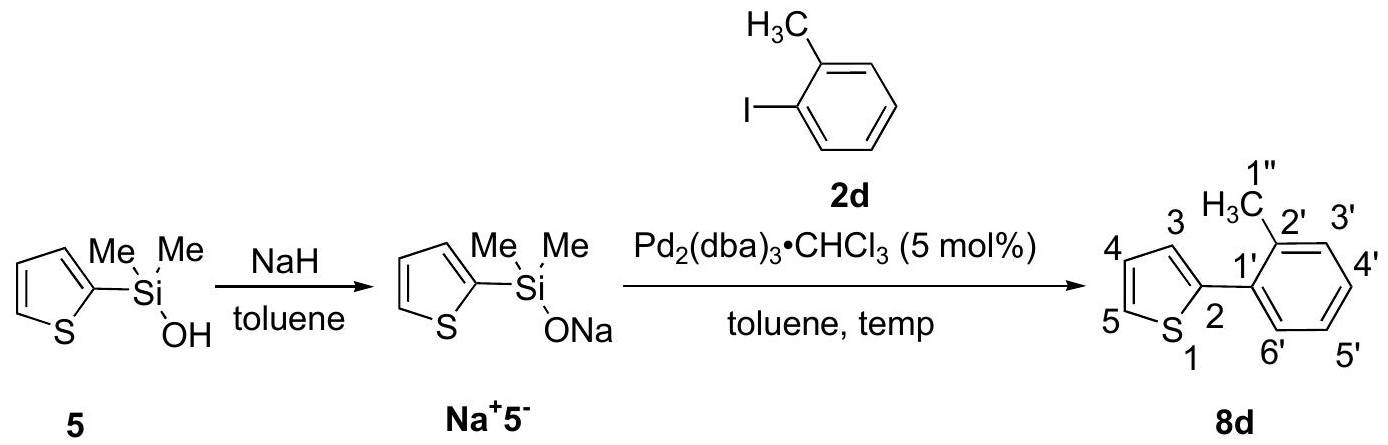

Following General Procedure I, a solution containing $29 \mathrm{mg}$ (1.2 mmol, 1.2 equiv) of $\mathrm{NaH}$, and $190 \mathrm{mg}$ of 2-thienyldimethylsilanol (1.2 mmol, 1.2 equiv) in $1.0 \mathrm{~mL}$ of toluene in a 5$\mathrm{mL}$ round-bottomed flask under an atmosphere of argon was prepared. To this mixture was added $218 \mathrm{mg}(1.0 \mathrm{mmol})$ of 1-iodo-2-methylbenzene, and $52 \mathrm{mg}(0.05 \mathrm{mmol}, 0.05 \mathrm{equiv})$ of $\mathrm{Pd}_{2}(\mathrm{dba})_{3} \cdot \mathrm{CHCl}_{3}$ and the mixture was stirred at $\mathrm{rt}$ for $3 \mathrm{~h}$. The reaction mixture was diluted with 
$25 \mathrm{~mL}$ of deionized $\mathrm{H}_{2} \mathrm{O}$, and $20 \mathrm{~mL}$ of EtOAc. The organic layer was separated, and the aqueous layer was washed with EtOAc (5 X $25 \mathrm{~mL})$. Purification by column chromatography $\left(\mathrm{SiO}_{2}(20 \mathrm{~mm}\right.$ X 100mm), toluene) and Kugelrohr distillation afforded $138 \mathrm{mg}(79 \%)$ of $8 \mathbf{d}$ as a clear, colorless oil. The physical and spectroscopic data matched those from the literature. ${ }^{9}$

Data for 8d:

bp: $\quad 125{ }^{\circ} \mathrm{C}(0.5 \mathrm{~mm} \mathrm{Hg}, \mathrm{ABT})$

1ㅁN $\underline{\text { NMR: }} \quad\left(500 \mathrm{MHz}, \mathrm{CHCl}_{3}\right)$

$7.42\left(\mathrm{dd}, J=7.2,1.6,1 \mathrm{H}, \mathrm{HC}\left(6^{\prime}\right)\right), 7.35$ (dd, $\left.J=5.1,1.2,1 \mathrm{H}, \mathrm{HC}(5)\right), 7.25$ (m, 3

H, HC(3'), HC(4'), HC(5')), 7.11 (dd, $J=5.0,3.5,1$ H, HC(4)), 7.08 (dd, $J=3.4$, 1.2, $1 \mathrm{H}, \mathrm{HC}(3)), 2.44$ (s, $\left.3 \mathrm{H}, \mathrm{HC}\left(1^{\prime \prime}\right)\right)$

${ }^{13}$ C NMR: $\quad\left(125 \mathrm{MHz}, \mathrm{CHCl}_{3}\right)$

$143.09(\mathrm{C}(2)), 136.07\left(\mathrm{C}\left(2^{\prime}\right)\right), 134.14\left(\mathrm{C}\left(1^{\prime}\right)\right), 130.70\left(\mathrm{C}\left(3^{\prime}\right)\right), 130.46\left(\mathrm{C}\left(4^{\prime}\right)\right)$, 127.77 (C(4)), 127.04 (C(3)), 126.35 (C(6')), 125.87 (C(5')), 125.07 (C(5)), 21.10 $\left(\mathrm{C}\left(1^{\prime \prime}\right)\right)$

TLC: $\quad R_{f} 0.57$ (hexane/EtOAc, 9/1) [silica gel, UV]

GC: $\quad t_{R} \mathbf{8 d}, 7.00 \min (98.7 \%)(\mathrm{HP}-5,15 \mathrm{psi})$

\section{Preparation of 2-(4'-Trifluoromethylphenyl)thiophene (8e)}

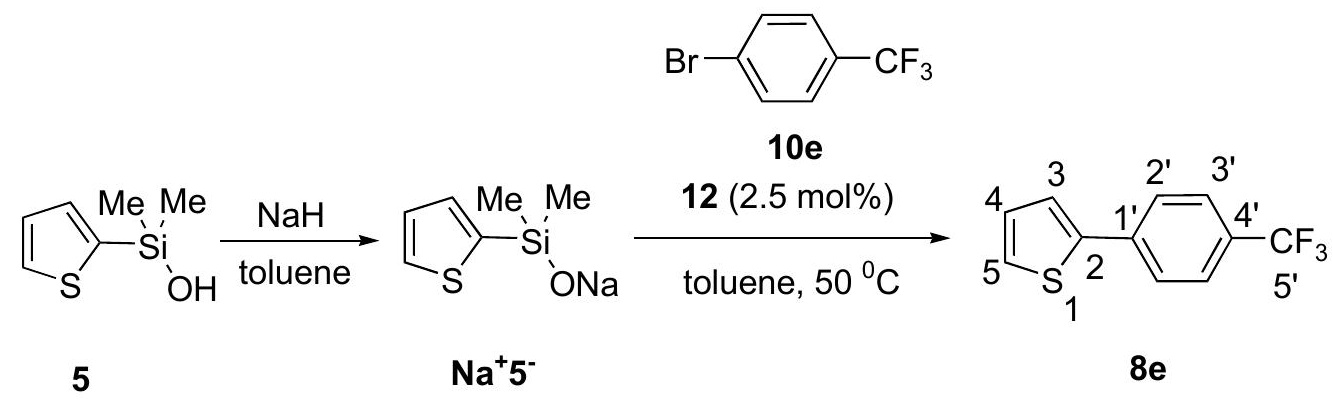

Following General Procedure II, a solution containing $29 \mathrm{mg}$ (1.2 mmol, 1.2 equiv) of $\mathrm{NaH}$, and $190 \mathrm{mg}$ of 2-thienyldimethylsilanol (1.2 mmol, 1.2 equiv) in $1.0 \mathrm{~mL}$ of toluene in a 5$\mathrm{mL}$ round-bottomed flask under an atmosphere of argon was prepared. To this mixture was added $140 \mu \mathrm{L}(1.0 \mathrm{mmol})$ of 4-bromobenzotrifluoride, and $18 \mathrm{mg}(0.025 \mathrm{mmol}, 0.025 \mathrm{equiv})$ of 12 and the mixture was stirred at $50{ }^{\circ} \mathrm{C}$ for $3 \mathrm{~h}$. The reaction mixture was diluted with $25 \mathrm{~mL}$ of deionized $\mathrm{H}_{2} \mathrm{O}$, and $20 \mathrm{~mL}$ of EtOAc. The organic layer was separated, and the aqueous layer 
was washed with EtOAc $(5 \mathrm{X} 25 \mathrm{~mL})$. Purification by column chromatography $\left(\mathrm{SiO}_{2}(20 \mathrm{~mm} \mathrm{X}\right.$ $100 \mathrm{~mm})$, toluene) and sublimation $\left(0.5 \mathrm{mmHg}, 50{ }^{\circ} \mathrm{C}\right)$ afforded $197 \mathrm{mg}(86 \%)$ of $8 \mathbf{e}$ as a white solid.

Data for 8e:

mp: $\quad 114-115^{\circ} \mathrm{C}$

1슬 $: \quad\left(500 \mathrm{MHz}, \mathrm{CHCl}_{3}\right)$

$7.71\left(\mathrm{~d}, J=8.3,2 \mathrm{H}, \mathrm{HC}\left(3^{\prime}\right)\right), 7.63$ (d, $\left.J=8.1,2 \mathrm{H}, \mathrm{HC}\left(2^{\prime}\right)\right), 7.40$ (dd, $J=3.7$, 1.2, $1 \mathrm{H}, \mathrm{HC}(5)), 7.36(\mathrm{dd}, J=5.0,1.1,1 \mathrm{H}, \mathrm{HC}(3)), 7.12(\mathrm{dd}, J=5.1,3.7,1 \mathrm{H}$, $\mathrm{HC}(4))$

${ }^{13}$ C NMR: $\quad\left(125 \mathrm{MHz}, \mathrm{CHCl}_{3}\right)$

$142.58(\mathrm{C}(2)), 137.72\left(\mathrm{C}\left(1^{\prime}\right)\right), 128.30$ (C(4')), $126.21(\mathrm{C}(4)), 125.92\left(\mathrm{C}\left(2^{\prime}\right)\right)$, $125.90(\mathrm{C}(4)), 125.85\left(\mathrm{C}\left(3^{\prime}\right)\right), 125.81$ (C(5)), $124.42\left(\mathrm{C}\left(5^{\prime}\right)\right)$

${ }^{19}$ F NMR:(470 MHz, $\mathrm{CDCl}_{3}$ )

$-60.7\left(\mathrm{FC}\left(5^{\prime}\right)\right)$

IR: (Nujol)

3430 (w), 2953 (s), 2924 (s), 2854 (s), 2361 (w), 2341 (w), 1615 (w), 1460 (w), $1377(w), 1340$ (w), 1326 (w), 1260 (w), 1170 (w), 1132 (w), 1111 (m), 1072 (w), $1016(\mathrm{w}), 959(\mathrm{w}), 855(\mathrm{w}), 844(\mathrm{w}), 823(\mathrm{w}), 708(\mathrm{w})$

MS: $\quad(\mathrm{EI}, 70 \mathrm{eV})$ $228\left(\mathrm{M}^{+}, 100\right), 209$ (9), 183 (12), 133 (5), 115 (7), 58 (5)

TLC: $\quad R_{f} 0.53$ (hexane/EtOAc, 9/1) [silica gel, UV]

GC: $\quad t_{R} \mathbf{8 e}, 6.82 \min (98.5 \%)(\mathrm{HP}-5,15 \mathrm{psi})$

Analysis: $\quad \mathrm{C}_{11} \mathrm{H}_{7} \mathrm{~F}_{3} \mathrm{~S}(228.23)$
Calcd:
C, 57.89;
$\mathrm{H}, 3.09 \%$
Found:
C, 57.61;
$\mathrm{H}, 3.39 \%$ 


\section{Preparation of 2-(4'-Naphthyl)thiophene (8f)}

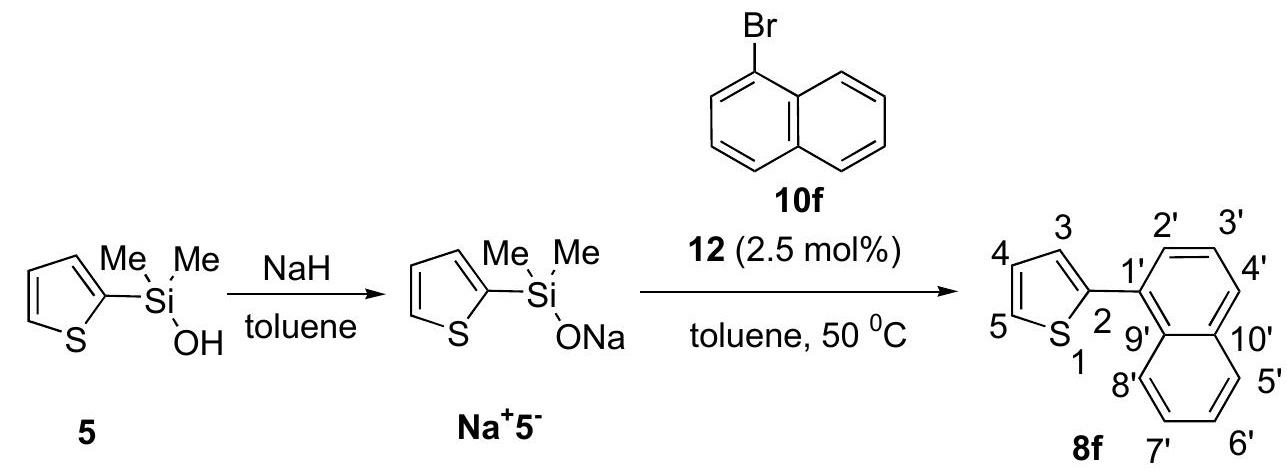

Following General Procedure II, a solution containing $29 \mathrm{mg}$ (1.2 mmol, 1.2 equiv) of $\mathrm{NaH}$, and $190 \mathrm{mg}$ of 2-thienyldimethylsilanol (1.2 mmol, 1.2 equiv) in $1.0 \mathrm{~mL}$ of toluene in a 5$\mathrm{mL}$ round-bottomed flask under an atmosphere of argon was prepared. To this mixture was added $139 \mu \mathrm{L}$ (1.0 mmol) of 1-bromonaphthalene, and $18 \mathrm{mg}(0.025 \mathrm{mmol}, 0.025$ equiv) of 12 and the mixture was stirred at $50{ }^{\circ} \mathrm{C}$ for $7 \mathrm{~h}$. The reaction mixture was diluted with $25 \mathrm{~mL}$ of deionized $\mathrm{H}_{2} \mathrm{O}$, and $20 \mathrm{~mL}$ of EtOAc. The organic layer was separated, and the aqueous layer was washed with EtOAc $(5 \mathrm{X} 25 \mathrm{~mL})$. Purification by column chromatography $\left(\mathrm{SiO}_{2}(20 \mathrm{~mm} \mathrm{X}\right.$ $100 \mathrm{~mm})$, toluene) and distillation afforded $156 \mathrm{mg}(74 \%)$ of $\mathbf{8 f}$ as a clear, colorless liquid.

\section{Data for 8f:}

bp: $\quad 160{ }^{\circ} \mathrm{C}(0.5 \mathrm{~mm} \mathrm{Hg}, \mathrm{ABT})$

${ }^{1} \underline{\text { H NMR: }} \quad\left(500 \mathrm{MHz}, \mathrm{CHCl}_{3}\right)$

$8.23(\mathrm{~m}, 1 \mathrm{H}), 7.90(\mathrm{~m}, 1 \mathrm{H}), 7.87$ (d, $J=8.3,1 \mathrm{H},), 7.58$ (d, $J=7.1,1 \mathrm{H}), 7.51$ $(\mathrm{m}, 3 \mathrm{H})), 7.44(\mathrm{dd}, J=5.2,1.1,1 \mathrm{H}, \mathrm{HC}(5)), 7.26(\mathrm{dd}, J=3.4,1.2,1 \mathrm{H}, \mathrm{HC}(3))$, $7.20(\mathrm{dd}, J=5.1,3.4,1 \mathrm{H}, \mathrm{HC}(4))$

${ }^{13} \underline{\mathrm{C} \mathrm{NMR}}: \quad\left(125 \mathrm{MHz}, \mathrm{CHCl}_{3}\right)$

141.77 (C(2)), 133.84 (C(1’)), 132.44 (C(10’)), 131.87 (C(9')), 128.39 (C(8')), 128.32 (C(5')), 128.20 (C(4’)), 127.38 (C(4)), 127.27 (C(3)), 126.44 (C(7’’)), $126.00\left(\mathrm{C}\left(6^{\prime}\right)\right), 125.75\left(\mathrm{C}\left(3^{\prime}\right)\right), 125.63(\mathrm{C}(5)), 125.24\left(\mathrm{C}\left(2^{\prime}\right)\right)$

IR: (neat) 3425 (w), 3104 (w), 3049 (w), 1931 (w), 1813 (w), 1676 (w), 1638 (w), 1590 (w), 1506 (w), 1436 (w), 1390 (m), 1327 (w), 1270 (w), 1244 (w), 1220 (w), 1209 (w), 
$1175(w), 1143$ (w), 1077 (w), 1043 (w), $1017(w), 969$ (w), 954 (w), 932 (w), $900(\mathrm{w}), 852(\mathrm{~m}), 836(\mathrm{w}), 796(\mathrm{~s}), 775(\mathrm{~s}), 735(\mathrm{w}), 699(\mathrm{~s}), 640(\mathrm{w}), 620(\mathrm{w})$

$\underline{\mathrm{MS}}$ : $\quad(\mathrm{EI}, 70 \mathrm{eV})$ $210\left(\mathrm{M}^{+}, 100\right), 209$ (41), 208 (18), 165 (22)

TLC: $\quad R_{f} 0.50$ (hexane/EtOAc, 9/1) [silica gel, UV]

GC: $\quad t_{R} \mathbf{8 f}, 10.46 \min (100.0 \%)(\mathrm{HP}-5,15 \mathrm{psi})$

Analysis: $\quad \mathrm{C}_{14} \mathrm{H}_{10} \mathrm{~S}(210.29)$

$\begin{array}{lll}\text { Calcd: } & \text { C, 79.96; } & \text { H, } 4.79 \% \\ \text { Found: } & \text { C, 79.70; } & \text { H, } 4.75 \%\end{array}$

\section{Preparation of 2-(4'-Methoxyphenyl)furan (9a)}

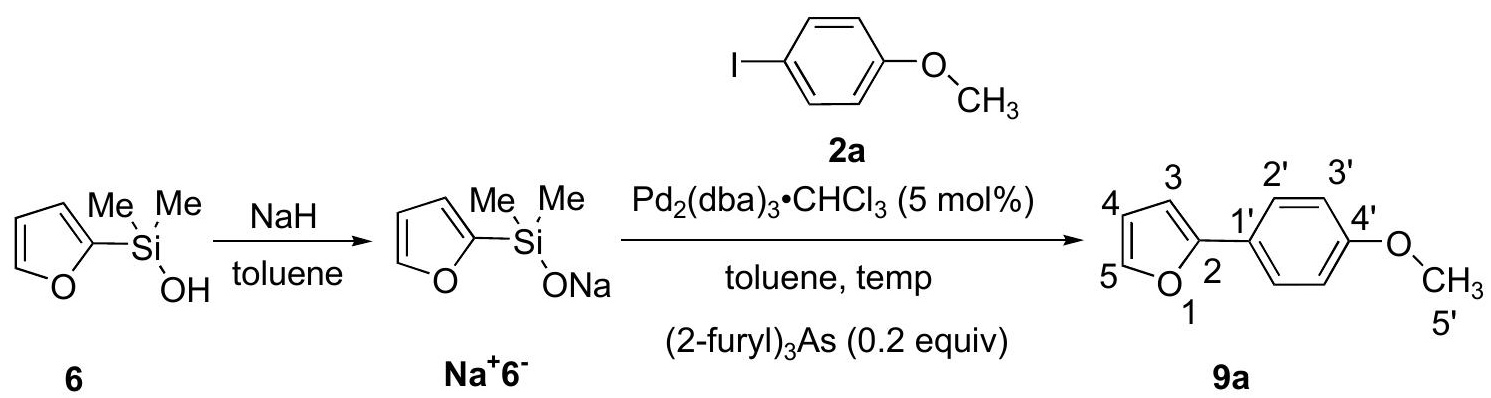

Following General Procedure I, a solution containing $29 \mathrm{mg}$ (1.2 mmol, 1.2 equiv) of $\mathrm{NaH}$, and $170 \mathrm{mg}$ of 2-furyldimethylsilanol (1.2 mmol, 1.2 equiv) in $1.0 \mathrm{~mL}$ of toluene in a 5 $\mathrm{mL}$ round-bottomed flask under an atmosphere of argon was prepared. To this mixture was added $234 \mathrm{mg}(1.0 \mathrm{mmol})$ of 1-iodo-4-methoxybenzene, $46 \mathrm{mg}$ (0.2 mmol, 0.2 equiv) of (2furyl $)_{3} \mathrm{P}$ and $52 \mathrm{mg}\left(0.05 \mathrm{mmol}, 0.05\right.$ equiv) of $\mathrm{Pd}_{2}(\mathrm{dba})_{3} \cdot \mathrm{CHCl}_{3}$ and the mixture was stirred at 50 ${ }^{0} \mathrm{C}$ for $24 \mathrm{~h}$. The reaction mixture was diluted with $25 \mathrm{~mL}$ of deionized $\mathrm{H}_{2} \mathrm{O}$, and $20 \mathrm{~mL}$ of EtOAc. The organic layer was separated, and the aqueous layer was washed with EtOAc (5 X 25 $\mathrm{mL})$. Purification by column chromatography $\left(\mathrm{SiO}_{2}(20 \mathrm{~mm} \times 100 \mathrm{~mm})\right.$, toluene $)$ and sublimation $\left(0.5 \mathrm{mmHg}, 50{ }^{\circ} \mathrm{C}\right)$ afforded $124 \mathrm{mg}(71 \%)$ of $9 \mathbf{a}$ as a white solid. The physical and spectroscopic data matched those from the literature. ${ }^{10}$

\section{Data for 9a:}

mp: $\quad 54-55^{\circ} \mathrm{C}$ 
$1_{\text {H NMR: }} \quad\left(500 \mathrm{MHz}, \mathrm{CHCl}_{3}\right)$

7.60 (d, $J=8.8,2$ H, HC(2')), 7.43 (d, $J=1.7,1 \mathrm{H}, \mathrm{HC}(5)), 6.92$ (d, $J=8.5,2 \mathrm{H}$, HC(3’)), 6.51 (d, $J=3.4,1$ H, HC(3)), 6.45 (dd, $J=3.4,1.7,1$ H, HC(4)), 3.84 (s, $\left.3 \mathrm{H}, \mathrm{HC}\left(5^{\prime}\right)\right)$

${ }^{13} \mathrm{C}$ NMR: $\quad\left(125 \mathrm{MHz}, \mathrm{CHCl}_{3}\right)$

$159.22\left(\mathrm{C}\left(4^{\prime}\right)\right), 154.25(\mathrm{C}(2)), 141.61(\mathrm{C}(5)), 125.45\left(\mathrm{C}\left(2^{\prime}\right)\right), 124.25\left(\mathrm{C}\left(1^{\prime}\right)\right)$, $114.32\left(\mathrm{C}\left(3^{\prime}\right)\right), 111.77(\mathrm{C}(3)), 103.60(\mathrm{C}(4)), 55.54\left(\mathrm{C}\left(5^{\prime}\right)\right)$

TLC: $\quad R_{f} 0.34$ (hexane/EtOAc, 9/1) [silica gel, UV]

GC: $\quad t_{R} 9 \mathbf{a}, 7.29 \min (98.2 \%)(\mathrm{HP}-5,15 \mathrm{psi})$

Preparation of 2-(4'-Ethoxycarbonylphenyl)furan (9b)

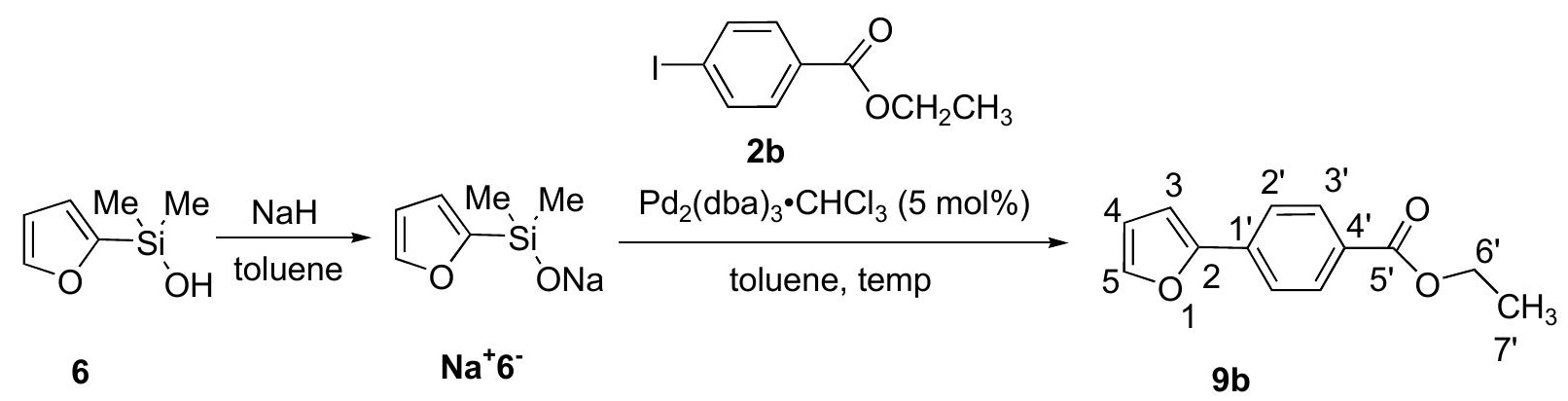

Following General Procedure I, a solution containing $29 \mathrm{mg}$ (1.2 mmol, 1.2 equiv) of $\mathrm{NaH}$, and $170 \mathrm{mg}$ of 2-furyldimethylsilanol ( $1.2 \mathrm{mmol}, 1.2$ equiv) in $1.0 \mathrm{~mL}$ of toluene in a 5 $\mathrm{mL}$ round-bottomed flask under an atmosphere of argon was prepared. To this mixture was added $276 \mathrm{mg}(1.0 \mathrm{mmol})$ of ethyl-4-iodo-benzoate, and $52 \mathrm{mg}(0.05 \mathrm{mmol}, 0.05$ equiv) of $\mathrm{Pd}_{2}(\mathrm{dba})_{3} \cdot \mathrm{CHCl}_{3}$ and the mixture was stirred at $\mathrm{rt}$ for $1 \mathrm{~h}$. The reaction mixture was diluted with $25 \mathrm{~mL}$ of deionized $\mathrm{H}_{2} \mathrm{O}$, and $20 \mathrm{~mL}$ of EtOAc. The organic layer was separated, and the aqueous layer was washed with EtOAc ( 5 X $25 \mathrm{~mL})$. Purification by column chromatography $\left(\mathrm{SiO}_{2}(20 \mathrm{~mm} \mathrm{X} 100 \mathrm{~mm})\right.$, toluene) and sublimation $\left(0.5 \mathrm{mmHg}, 50{ }^{\circ} \mathrm{C}\right)$ afforded $178 \mathrm{mg}(82 \%)$ of $\mathbf{9 b}$ as a white solid. The physical and spectroscopic data matched those from the literature. ${ }^{10}$ Data for $9 \mathbf{b}$ :

mp: $\quad 55-56{ }^{\circ} \mathrm{C}$ 
$1_{\text {H NMR: }} \quad\left(500 \mathrm{MHz}, \mathrm{CHCl}_{3}\right)$

$8.06\left(\mathrm{~d}, J=8.6,2 \mathrm{H}, \mathrm{HC}\left(3^{\prime}\right)\right), 7.72\left(\mathrm{~d}, J=8.8,2 \mathrm{H}, \mathrm{HC}\left(2^{\prime}\right)\right), 7.52(\mathrm{~d}, J=1.8,1 \mathrm{H}$, $\mathrm{HC}(5)), 6.79$ (d, $J=3.3,1 \mathrm{H}, \mathrm{HC}(3)), 6.51$ (dd, $J=3.4,2.0,1 \mathrm{H}, \mathrm{HC}(4)), 4.39$ (q, $\left.J=7.2,2 \mathrm{H}, \mathrm{HC}\left(6^{\prime}\right)\right), 1.41\left(\mathrm{t}, 3 \mathrm{H}, \mathrm{HC}\left(7^{\prime}\right)\right)$

${ }^{13} \mathrm{C}$ NMR: $\quad\left(125 \mathrm{MHz}, \mathrm{CHCl}_{3}\right)$

$166.32\left(\mathrm{C}\left(5^{\prime}\right)\right), 152.94(\mathrm{C}(2)), 143.067(\mathrm{C}(5)), 134.63\left(\mathrm{C}\left(1^{\prime}\right)\right), 130.04\left(\mathrm{C}\left(3^{\prime}\right)\right)$, $128.85\left(\mathrm{C}\left(4^{\prime}\right)\right), 123.32\left(\mathrm{C}\left(2^{\prime}\right)\right), 111.99(\mathrm{C}(3)), 107.14(\mathrm{C}(4)), 60.91\left(\mathrm{C}\left(6^{\prime}\right)\right), 14.29$ $\left(\mathrm{C}\left(7^{\prime}\right)\right)$

TLC: $\quad R_{f} 0.20$ (hexane/EtOAc, 9/1) [silica gel, UV]

GC: $\quad t_{R} 9 \mathbf{b}, 8.99 \min (100.0 \%)(\mathrm{HP}-5,15 \mathrm{psi})$

\section{Preparation of 2-(4'-Cyanophenyl)furan (9c)}

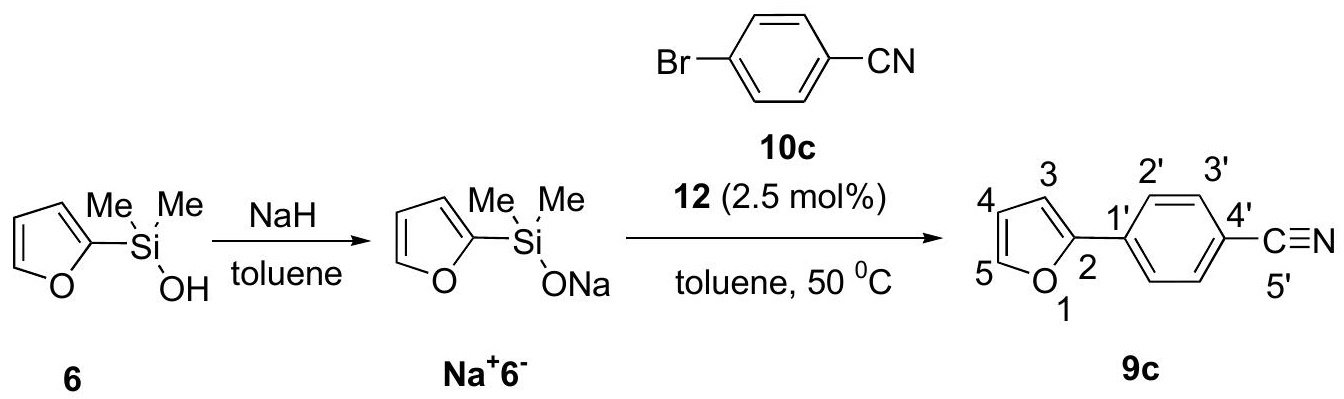

Following General Procedure II, a solution containing $29 \mathrm{mg}$ (1.2 mmol, 1.2 equiv) of $\mathrm{NaH}$, and $170 \mathrm{mg}$ of 2-furyldimethylsilanol $(1.2 \mathrm{mmol}, 1.2$ equiv) in $1.0 \mathrm{~mL}$ of toluene in a $5-$ $\mathrm{mL}$ round-bottomed flask under an atmosphere of argon was prepared. To this mixture was added $182 \mathrm{mg}$ ( $1.0 \mathrm{mmol})$ of 1-bromo-4-cyanobenzene, and $18 \mathrm{mg}(0.025 \mathrm{mmol}, 0.025$ equiv) of 12 and the mixture was stirred at $50{ }^{\circ} \mathrm{C}$ for $3 \mathrm{~h}$. The reaction mixture was diluted with $25 \mathrm{~mL}$ of deionized $\mathrm{H}_{2} \mathrm{O}$, and $20 \mathrm{~mL}$ of EtOAc. The organic layer was separated, and the aqueous layer was washed with EtOAc $(5 \mathrm{X} 25 \mathrm{~mL})$. Purification by column chromatography $\left(\mathrm{SiO}_{2}(20 \mathrm{~mm} \mathrm{X}\right.$ $100 \mathrm{~mm})$, toluene) and sublimation $\left(0.5 \mathrm{mmHg}, 50{ }^{\circ} \mathrm{C}\right)$ afforded $123 \mathrm{mg}(73 \%)$ of $\mathbf{9 c}$ as a white solid. The physical and spectroscopic data matched those from the literature. ${ }^{11}$

Data for $9 \mathrm{c}$ :

mp: $\quad 54-56{ }^{\circ} \mathrm{C}$ 
$1_{\text {H NMR: }} \quad\left(500 \mathrm{MHz}, \mathrm{CHCl}_{3}\right)$

$7.75\left(\mathrm{~d}, J=8.1,2 \mathrm{H}, \mathrm{HC}\left(2^{\prime}\right)\right), 7.66\left(\mathrm{~d}, J=8.1,2 \mathrm{H}, \mathrm{HC}\left(3^{\prime}\right)\right), 7.54(\mathrm{~d}, J=1.7,1 \mathrm{H}$, $\mathrm{HC}(5)), 6.82(\mathrm{~d}, J=3.4,1 \mathrm{H}, \mathrm{HC}(3)), 6.53(\mathrm{dd}, J=3.4,1.7,1 \mathrm{H}, \mathrm{HC}(4))$

${ }^{13}$ C NMR: $\quad\left(125 \mathrm{MHz}, \mathrm{CHCl}_{3}\right)$

$151.85(\mathrm{C}(2)), 143.62(\mathrm{C}(5)), 134.52\left(\mathrm{C}\left(1^{\prime}\right)\right), 132.48\left(\mathrm{C}\left(3^{\prime}\right)\right), 123.83\left(\mathrm{C}\left(2^{\prime}\right)\right)$, $118.90\left(\mathrm{C}\left(5^{\prime}\right)\right), 112.18\left(\mathrm{C}\left(4^{\prime}\right)\right), 110.12(\mathrm{C}(3)), 108.10(\mathrm{C}(4))$

MS: $\quad(E I, 70 \mathrm{eV})$ $169\left(\mathrm{M}^{+}, 100\right), 141$ (18), 140 (66), 114 (15), 113 (10), 63 (6)

TLC: $\quad R_{f} 0.18$ (hexane/EtOAc, 9/1) [silica gel, UV]

\section{Preparation of 2-(2'-Methylphenyl)furan (9d)}

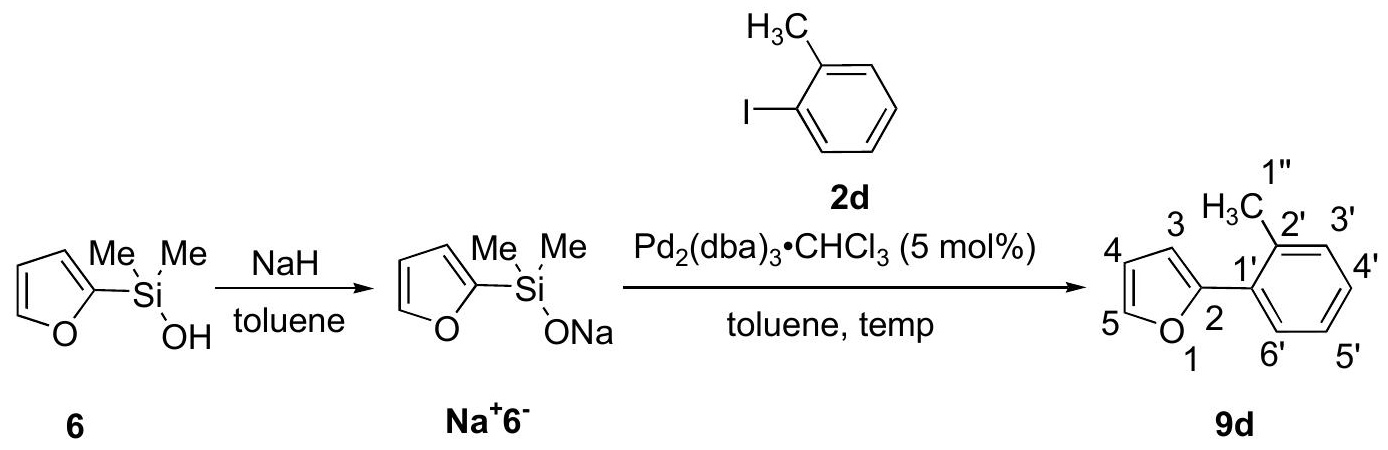

Following General Procedure I, a solution containing $29 \mathrm{mg}$ (1.2 mmol, 1.2 equiv) of $\mathrm{NaH}$, and $170 \mathrm{mg}$ of 2-furyldimethylsilanol (1.2 mmol, 1.2 equiv) in $1.0 \mathrm{~mL}$ of toluene in a 5$\mathrm{mL}$ round-bottomed flask under an atmosphere of argon was prepared. To this mixture was added $218 \mathrm{mg}(1.0 \mathrm{mmol})$ of 1-iodo-2-methylbenzene, and $52 \mathrm{mg}(0.05 \mathrm{mmol}, 0.05$ equiv $)$ of $\mathrm{Pd}_{2}(\mathrm{dba})_{3} \cdot \mathrm{CHCl}_{3}$ and the mixture was stirred at $\mathrm{rt}$ for $3 \mathrm{~h}$. The reaction mixture was diluted with $25 \mathrm{~mL}$ of deionized $\mathrm{H}_{2} \mathrm{O}$, and $20 \mathrm{~mL}$ of EtOAc. The organic layer was separated, and the aqueous layer was washed with EtOAc (5 X $25 \mathrm{~mL})$. Purification by column chromatography $\left(\mathrm{SiO}_{2}(20 \mathrm{~mm}\right.$ X 100mm), toluene) and Kugelrohr distillation afforded $97 \mathrm{mg}(61 \%)$ of $9 d$ as a clear, colorless oil. The physical and spectroscopic data matched those from the literature. ${ }^{12}$ Data for 9d:

bp: $\quad 105{ }^{\circ} \mathrm{C}(0.5 \mathrm{~mm} \mathrm{Hg}, \mathrm{ABT})$ 
$1_{\text {H NMR: }} \quad\left(500 \mathrm{MHz}, \mathrm{CHCl}_{3}\right)$

$7.70\left(\mathrm{~d}, J=7.8,1 \mathrm{H}, \mathrm{HC}\left(6^{\prime}\right)\right), 7.51$ (d, $\left.J=1.7,1 \mathrm{H}, \mathrm{HC}(5)\right), 7.23$ (m, $3 \mathrm{H}, \mathrm{HC}\left(3^{\prime}\right)$, $\left.\mathrm{HC}\left(4^{\prime}\right), \mathrm{HC}\left(5^{\prime}\right)\right), 6.55(\mathrm{~d}, J=3.2,1 \mathrm{H}, \mathrm{HC}(3)), 6.51(\mathrm{dd}, J=3.3,1.8,1 \mathrm{H}$, $\mathrm{HC}(4)), 2.50$ (s, $3 \mathrm{H}, \mathrm{HC}(1$ ''))

${ }^{13} \mathrm{C}$ NMR: $\quad\left(125 \mathrm{MHz}, \mathrm{CHCl}_{3}\right)$

$153.55(\mathrm{C}(2)), 141.65(\mathrm{C}(5)), 134.55\left(\mathrm{C}\left(2^{\prime}\right)\right), 131.11\left(\mathrm{C}\left(1^{\prime}\right)\right), 130.22\left(\mathrm{C}\left(3^{\prime}\right)\right)$, $127.44\left(\mathrm{C}\left(4^{\prime}\right)\right), 127.04\left(\mathrm{C}\left(6^{\prime}\right)\right), 125.97\left(\mathrm{C}\left(5^{\prime}\right)\right), 111.28(\mathrm{C}(3)), 108.47(\mathrm{C}(4))$, $21.84(\mathrm{C}(1)$,

TLC: $\quad R_{f} 0.55$ (hexane/EtOAc, 9/1) [silica gel, UV]

GC: $\quad t_{R}$ 9d, $6.30 \mathrm{~min}(100.0 \%)(\mathrm{HP}-5,15 \mathrm{psi})$

\section{Preparation of 2-(4'-Trifluoromethylphenyl)furan (9e)}

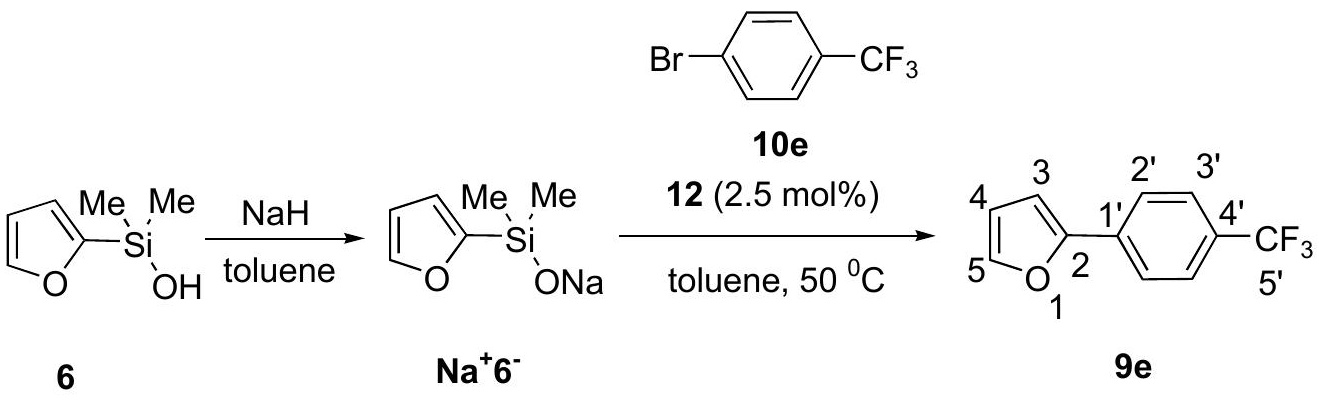

Following General Procedure II, a solution containing $29 \mathrm{mg}$ (1.2 mmol, 1.2 equiv) of $\mathrm{NaH}$, and $170 \mathrm{mg}$ of 2-furyldimethylsilanol ( $1.2 \mathrm{mmol}, 1.2$ equiv) in $1.0 \mathrm{~mL}$ of toluene in a 5 $\mathrm{mL}$ round-bottomed flask under an atmosphere of argon was prepared. To this mixture was added $140 \mu \mathrm{L}$ (1.0 mmol) of 4-bromobenzotrifluoride, and $18 \mathrm{mg}(0.025 \mathrm{mmol}, 0.025$ equiv) of 12 whereupon the mixture was stirred at $50{ }^{\circ} \mathrm{C}$ for $3 \mathrm{~h}$. The reaction mixture was diluted with 25 $\mathrm{mL}$ of deionized $\mathrm{H}_{2} \mathrm{O}$, and $20 \mathrm{~mL}$ of EtOAc. The organic layer was separated, and the aqueous layer was washed with EtOAc $(5 \mathrm{X} 25 \mathrm{~mL})$. Purification by column chromatography $\left(\mathrm{SiO}_{2}(20\right.$ $\mathrm{mm} X 100 \mathrm{~mm})$, toluene) and sublimation $\left(0.5 \mathrm{mmHg}, 50{ }^{\circ} \mathrm{C}\right)$ afforded $150 \mathrm{mg}(71 \%)$ of $9 \mathrm{e}$ as a white solid. The physical and spectroscopic data matched those from the literature. ${ }^{13}$

Data for $9 \mathrm{e}$ :

mp: $\quad 88-89^{\circ} \mathrm{C}$ 
$1_{\text {H NMR: }} \quad\left(500 \mathrm{MHz}, \mathrm{CHCl}_{3}\right)$

$7.77\left(\mathrm{~d}, J=8.1,2 \mathrm{H}, \mathrm{HC}\left(3^{\prime}\right)\right), 7.63\left(\mathrm{~d}, J=8.3,2 \mathrm{H}, \mathrm{HC}\left(2^{\prime}\right)\right), 7.52(\mathrm{~d}, J=1.5,1 \mathrm{H}$, $\mathrm{HC}(5)), 6.77$ (d, $J=3.2,1 \mathrm{H}, \mathrm{HC}(3)), 6.51(\mathrm{dd}, J=3.4,2.0,1 \mathrm{H}, \mathrm{HC}(4))$

${ }^{13} \mathrm{C} \mathrm{NMR}: \quad\left(125 \mathrm{MHz}, \mathrm{CHCl}_{3}\right)$

$152.51(\mathrm{C}(2)), 143.10(\mathrm{C}(5)), 133.93\left(\mathrm{C}\left(1^{\prime}\right)\right), 125.72\left(\mathrm{C}\left(4^{\prime}\right)\right), 125.70\left(\mathrm{C}\left(2^{\prime}\right)\right)$, $125.66\left(\mathrm{C}\left(3^{\prime}\right)\right), 123.75\left(\mathrm{C}\left(5^{\prime}\right)\right), 111.96(\mathrm{C}(3)), 106.96(\mathrm{C}(4))$

TLC: $\quad R_{f} 0.46$ (hexane/EtOAc, 9/1) [silica gel, UV]

GC: $\quad t_{R}$ 9e, $5.95 \min (100.0 \%)(\mathrm{HP}-5,15 \mathrm{psi})$

Preparation of 2-(4'-Naphthyl)furan (9f)

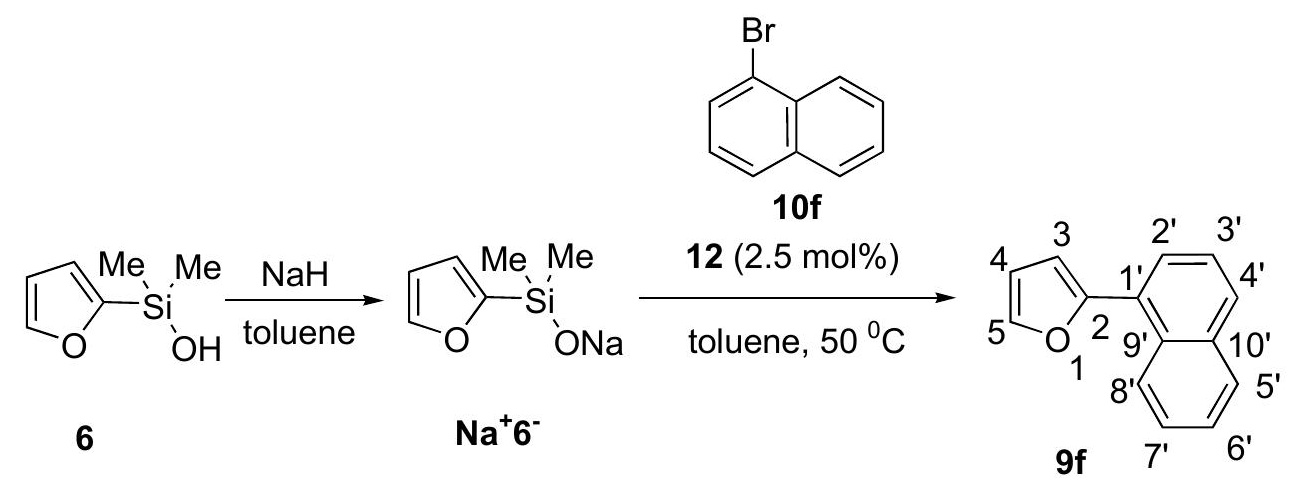

Following General Procedure II, a solution containing $29 \mathrm{mg}$ (1.2 mmol, 1.2 equiv) of $\mathrm{NaH}$, and $170 \mathrm{mg}$ of 2-furyldimethylsilanol ( $1.2 \mathrm{mmol}, 1.2$ equiv) in $1.0 \mathrm{~mL}$ of toluene in a 5$\mathrm{mL}$ round-bottomed flask under an atmosphere of argon was prepared. To this mixture was added $139 \mu \mathrm{L}$ (1.0 mmol) of 1-bromonaphthalene, and $18 \mathrm{mg}$ ( $0.025 \mathrm{mmol}, 0.025$ equiv) of $\mathbf{1 2}$ and the mixture was stirred at $50{ }^{\circ} \mathrm{C}$ for $6 \mathrm{~h}$. The reaction mixture was diluted with $25 \mathrm{~mL}$ of deionized $\mathrm{H}_{2} \mathrm{O}$, and $20 \mathrm{~mL}$ of EtOAc. The organic layer was separated, and the aqueous layer was washed with EtOAc $(5 \mathrm{X} 25 \mathrm{~mL})$. Purification by column chromatography $\left(\mathrm{SiO}_{2}(20 \mathrm{~mm} \mathrm{X}\right.$ $100 \mathrm{~mm})$, toluene) and distillation afforded $134 \mathrm{mg}(69 \%)$ of $9 \mathrm{f}$ as a clear, colorless oil. The physical and spectroscopic data matched those from the literature. ${ }^{14}$

Data for 9f:

bp: $\quad 130{ }^{\circ} \mathrm{C}(0.5 \mathrm{~mm} \mathrm{Hg}, \mathrm{ABT})$ 
$1_{\text {H NMR: }} \quad\left(500 \mathrm{MHz}, \mathrm{CHCl}_{3}\right)$

$8.42(\mathrm{~d}, J=7.8,1 \mathrm{H}), 7.90(\mathrm{~d}, J=7.3,1 \mathrm{H}$ ) $, 7.85(\mathrm{~d}, J=8.3,1 \mathrm{H}), 7.75(\mathrm{~d}, J=$ 7.3, $1 \mathrm{H}), 7.64(\mathrm{~d}, J=1.7,1 \mathrm{H}, \mathrm{HC}(5)), 7.54(\mathrm{~m}, 3 \mathrm{H}), 6.74(\mathrm{~d}, J=3.2,1 \mathrm{H}$, $\mathrm{HC}(3)), 6.60$ (dd, $J=3.2,2.0,1 \mathrm{H}, \mathrm{HC}(4))$

${ }^{13} \mathrm{C}$ NMR: $\quad\left(125 \mathrm{MHz}, \mathrm{CHCl}_{3}\right)$

$153.45(\mathrm{C}(2)), 142.40(\mathrm{C}(5)), 133.93\left(\mathrm{C}\left(1^{\prime}\right)\right), 130.36\left(\mathrm{C}\left(10^{\prime}\right)\right), 128.57\left(\mathrm{C}\left(9^{\prime}\right)\right)$, $128.54\left(\mathrm{C}\left(5^{\prime}\right)\right), 128.50\left(\mathrm{C}\left(8^{\prime}\right)\right), 126.53\left(\mathrm{C}\left(4^{\prime}\right)\right), 126.14\left(\mathrm{C}\left(3^{\prime}\right)\right), 125.90\left(\mathrm{C}\left(7^{\prime}\right)\right)$, $125.53\left(\mathrm{C}\left(6^{\prime}\right)\right), 125.30\left(\mathrm{C}\left(2^{\prime}\right)\right), 111.36(\mathrm{C}(3)), 109.19(\mathrm{C}(4))$

TLC: $\quad R_{f} 0.62$ (hexane/EtOAc, 9/1) [silica gel, UV]

GC: $\quad t_{R}$ 9f, $8.96 \min (98.3 \%)(\mathrm{HP}-5,15 \mathrm{psi})$

\section{Table 4, entry 1}

Following General Procedure II, a solution containing $29 \mathrm{mg}$ (1.2 mmol, 1.2 equiv) of $\mathrm{NaH}$, and $190 \mathrm{mg}$ of 2-thienyldimethylsilanol (1.2 mmol, 1.2 equiv) in $1.0 \mathrm{~mL}$ of toluene in a 5-mL roundbottomed flask under an atmosphere of argon was prepared. To this mixture was added $125 \mu \mathrm{L}$ (1.0 mmol) of 1-bromo-4-methoxybenzene, and $18 \mathrm{mg}(0.025 \mathrm{mmol}, 0.025$ equiv) of 12 and the mixture was stirred at $50{ }^{\circ} \mathrm{C}$ for $3 \mathrm{~h}$. The reaction mixture was diluted with $25 \mathrm{~mL}$ of deionized $\mathrm{H}_{2} \mathrm{O}$, and $20 \mathrm{~mL}$ of EtOAc. The organic layer was separated, and the aqueous layer was washed with EtOAc (5 X $25 \mathrm{~mL})$. Purification by column chromatography $\left(\mathrm{SiO}_{2}(20 \mathrm{~mm} \mathrm{X100mm})\right.$, toluene) and sublimation $\left(0.5 \mathrm{mmHg}, 50{ }^{\circ} \mathrm{C}\right)$ afforded $135 \mathrm{mg}(71 \%)$ of $8 \mathbf{a}$ as a white solid. $t_{R}$ 8a, $8.43 \min (100.0 \%)(\mathrm{HP}-5,15 \mathrm{psi})$.

\section{Table 4, entry 2}

Following General Procedure II, a solution containing $29 \mathrm{mg}$ (1.2 mmol, 1.2 equiv) of $\mathrm{NaH}$, and $190 \mathrm{mg}$ of 2-thienyldimethylsilanol (1.2 mmol, 1.2 equiv) in $1.0 \mathrm{~mL}$ of toluene in a 5$\mathrm{mL}$ round-bottomed flask under an atmosphere of argon was prepared. To this mixture was added $163 \mu \mathrm{L}(1.0 \mathrm{mmol})$ of ethyl-4-bromo-benzoate, and $18 \mathrm{mg}(0.025 \mathrm{mmol}, 0.025$ equiv) of 12 and the mixture was stirred at $50{ }^{\circ} \mathrm{C}$ for $3 \mathrm{~h}$. The reaction mixture was diluted with $25 \mathrm{~mL}$ of deionized $\mathrm{H}_{2} \mathrm{O}$, and $20 \mathrm{~mL}$ of EtOAc. The organic layer was separated, and the aqueous layer was washed with EtOAc $(5 \mathrm{X} 25 \mathrm{~mL})$. Purification by column chromatography $\left(\mathrm{SiO}_{2}(20 \mathrm{~mm} \mathrm{X}\right.$ 
$100 \mathrm{~mm})$, toluene) and sublimation $\left(0.5 \mathrm{mmHg}, 50{ }^{\circ} \mathrm{C}\right)$ afforded $155 \mathrm{mg}(67 \%)$ of $\mathbf{8 b}$ as a white solid. $t_{R} \mathbf{8 b}, 10.89 \min (100.0 \%)$ (HP-5, 15 psi).

\section{Table 4, entry 4}

Following General Procedure II, a solution containing $29 \mathrm{mg}$ (1.2 mmol, 1.2 equiv) of $\mathrm{NaH}$, and $190 \mathrm{mg}$ of 2-thienyldimethylsilanol (1.2 mmol, 1.2 equiv) in $1.0 \mathrm{~mL}$ of toluene in a 5$\mathrm{mL}$ round-bottomed flask under an atmosphere of argon was prepared. To this mixture was added $120 \mu \mathrm{L}(1.0 \mathrm{mmol})$ of 2-bromotoluene, and $18 \mathrm{mg}(0.025 \mathrm{mmol}, 0.025$ equiv $)$ of 12 and the mixture was stirred at $50{ }^{0} \mathrm{C}$ for $3 \mathrm{~h}$. The reaction mixture was diluted with $25 \mathrm{~mL}$ of deionized $\mathrm{H}_{2} \mathrm{O}$, and $20 \mathrm{~mL}$ of EtOAc. The organic layer was separated, and the aqueous layer was washed with EtOAc $(5$ X $25 \mathrm{~mL})$. Purification by column chromatography $\left(\mathrm{SiO}_{2}(20 \mathrm{~mm} \mathrm{X}\right.$ 100mm), hexane/EtOAc 9/1) and distillation afforded $134 \mathrm{mg}(77 \%)$ of $8 \mathbf{d}$ as a clear, colorless oil. $t_{R} \mathbf{8 d}, 6.99 \min (100.0 \%)(\mathrm{HP}-5,15 \mathrm{psi})$.

\section{Table 4, entry 7}

Following General Procedure II, a solution containing $29 \mathrm{mg}$ (1.2 mmol, 1.2 equiv) of $\mathrm{NaH}$, and $170 \mathrm{mg}$ of 2-furyldimethylsilanol (1.2 mmol, 1.2 equiv) in $1.0 \mathrm{~mL}$ of toluene in a 5$\mathrm{mL}$ round-bottomed flask under an atmosphere of argon was prepared. To this mixture was added $125 \mu \mathrm{L}(1.0 \mathrm{mmol})$ of 1-bromo-4-methoxybenzene, and $18 \mathrm{mg}$ (0.025 mmol, 0.025 equiv) of 12 and the mixture was stirred at $50{ }^{\circ} \mathrm{C}$ for $3 \mathrm{~h}$. The reaction mixture was diluted with $25 \mathrm{~mL}$ of deionized $\mathrm{H}_{2} \mathrm{O}$, and $20 \mathrm{~mL}$ of EtOAc. The organic layer was separated, and the aqueous layer was washed with EtOAc $(5 \mathrm{X} 25 \mathrm{~mL})$. Purification by column chromatography $\left(\mathrm{SiO}_{2}(20 \mathrm{~mm} \mathrm{X}\right.$ $100 \mathrm{~mm})$, toluene) and sublimation $\left(0.5 \mathrm{mmHg}, 50{ }^{\circ} \mathrm{C}\right)$ afforded $115 \mathrm{mg}(66 \%)$ of $9 \mathrm{a}$ as a white solid. $t_{R}$ 9a, $7.27 \mathrm{~min}(100.0 \%)$ (HP-5, $\left.15 \mathrm{psi}\right)$.

\section{Table 4, entry 8}

Following General Procedure II, a solution containing $29 \mathrm{mg}$ (1.2 mmol, 1.2 equiv) of $\mathrm{NaH}$, and $170 \mathrm{mg}$ of 2-furyldimethylsilanol (1.2 mmol, 1.2 equiv) in $1.0 \mathrm{~mL}$ of toluene in a 5 $\mathrm{mL}$ round-bottomed flask under an atmosphere of argon was prepared. To this mixture was added $163 \mu \mathrm{L}(1.0 \mathrm{mmol})$ of ethyl-4-bromo-benzoate, and $18 \mathrm{mg}(0.025 \mathrm{mmol}, 0.025$ equiv) of 12 andthe mixture was stirred at $50{ }^{\circ} \mathrm{C}$ for $3 \mathrm{~h}$. The reaction mixture was diluted with $25 \mathrm{~mL}$ of 
deionized $\mathrm{H}_{2} \mathrm{O}$, and $20 \mathrm{~mL}$ of EtOAc. The organic layer was separated, and the aqueous layer was washed with EtOAc ( 5 X $25 \mathrm{~mL})$. Purification by column chromatography $\left(\mathrm{SiO}_{2}(20 \mathrm{~mm} \mathrm{X}\right.$ $100 \mathrm{~mm})$, toluene) and sublimation afforded $130 \mathrm{mg}(60 \%)$ of $\mathbf{9 b}$ as a white solid. $t_{R} \mathbf{9 b}, 8.94$ $\min (100.0 \%)(\mathrm{HP}-5,15 \mathrm{psi})$.

\section{Table 4, entry 10}

Following General Procedure II, a solution containing $29 \mathrm{mg}$ (1.2 mmol, 1.2 equiv) of $\mathrm{NaH}$, and $170 \mathrm{mg}$ of 2-thienyldimethylsilanol (1.2 mmol, 1.2 equiv) in $1.0 \mathrm{~mL}$ of toluene in a 5$\mathrm{mL}$ round-bottomed flask under an atmosphere of argon was prepared. To this mixture was added $120 \mu \mathrm{L}$ (1.0 mmol) of 2-bromotoluene, and $18 \mathrm{mg}(0.025 \mathrm{mmol}, 0.025$ equiv) of 12 and the mixture was stirred at $50{ }^{0} \mathrm{C}$ for $3 \mathrm{~h}$. The reaction mixture was diluted with $25 \mathrm{~mL}$ of deionized $\mathrm{H}_{2} \mathrm{O}$, and $20 \mathrm{~mL}$ of EtOAc. The organic layer was separated, and the aqueous layer was washed with EtOAc $(5 \mathrm{X} 25 \mathrm{~mL})$. Purification by column chromatography $\left(\mathrm{SiO}_{2}(20 \mathrm{~mm} \mathrm{X}\right.$ 100mm), hexane/EtOAc 9/1) and distillation afforded $113 \mathrm{mg}(71 \%)$ of 9d as a clear, colorless oil. $t_{R}$ 9d, $6.31 \mathrm{~min}(100.0 \%)(\mathrm{HP}-5,15 \mathrm{psi})$.

\section{Cross-Coupling of Pre-formed Sodium Silanolates:}

Preparation of 2-(4'-Ethoxycarbonylphenyl)indole-1-carboxylic Acid tert-Butyl Ester (3b)

Following General Procedure III, a mixture of $376 \mathrm{mg}$ (1.2 mmol, 1.2 equiv) of $\mathbf{N a}^{+} \mathbf{1}^{-}$in $1.0 \mathrm{~mL}$ of dry toluene under dry argon atmosphere inside a dry box was prepared. To this mixture was added $168 \mu \mathrm{L}(1.0 \mathrm{mmol}, 1.0$ equiv) of ethyl-4-iodobenzoate and $52 \mathrm{mg}(0.05$ mmol, 0.05 equiv) of $\mathrm{Pd}_{2}(\mathrm{dba})_{3} \cdot \mathrm{CHCl}_{3}$. The flask was sealed with a rubber septum and removed from the drybox.

After being stirred at $\mathrm{rt}$ for $3 \mathrm{~h}$, the reaction mixture was diluted with $25 \mathrm{~mL}$ of deionized $\mathrm{H}_{2} \mathrm{O}$, and $20 \mathrm{~mL}$ of EtOAc. The organic layer was separated, and the aqueous layer was washed with EtOAc ( 5 X $25 \mathrm{~mL}$ ). The combined organic layers were dried over $\mathrm{MgSO}_{4}$ and were filtered through \#4 Whatman filter paper. The solvent was removed under reduced pressure to give a dark red residue. A solution of the residue in $0.5 \mathrm{~mL}$ of toluene was loaded onto a silica gel column $(20$ X $100 \mathrm{~mm})$ which was eluted with toluene (20 X $10 \mathrm{~mL}$ fractions). Evaporation of the solvent and further purification by recrystallization afforded $279 \mathrm{mg}(76 \%)$ of $\mathbf{3 b}$ as a white solid. 


\section{Preparation of 2-(4'-Ethoxycarbonylphenyl)thiophene (8b)}

Following General Procedure III, a solution of $216 \mathrm{mg}\left(1.2 \mathrm{mmol}, 1.2\right.$ equiv) of $\mathbf{N a}^{+} 5^{-}$in $1.0 \mathrm{~mL}$ of dry toluene under dry argon atmosphere inside a dry box was prepared. To this mixture was added $168 \mu \mathrm{L}(1.0 \mathrm{mmol}, 1.0$ equiv) of ethyl-4-iodobenzoate and $52 \mathrm{mg}(0.05$ mmol, 0.05 equiv) of $\mathrm{Pd}_{2}(\mathrm{dba})_{3} \cdot \mathrm{CHCl}_{3}$. The flask was sealed with a rubber septum and removed from the drybox.

After being stirred at $\mathrm{rt}$ for $3 \mathrm{~h}$, the reaction mixture was diluted with $25 \mathrm{~mL}$ of deionized $\mathrm{H}_{2} \mathrm{O}$, and $20 \mathrm{~mL}$ of EtOAc. The organic layer was separated, and the aqueous layer was washed with EtOAc ( 5 X $25 \mathrm{~mL}$ ). The combined organic layers were dried over $\mathrm{MgSO}_{4}$ and were filtered through \#4 Whatman filter paper. The solvent was removed under reduced pressure to give a dark red residue. A solution of the residue in $0.5 \mathrm{~mL}$ of toluene was loaded onto a silica gel column $(20$ X $100 \mathrm{~mm})$ which was eluted with toluene (20 X $10 \mathrm{~mL}$ fractions). Evaporation of the solvent and further purification by sublimation $\left(0.5 \mathrm{mmHg}, 50{ }^{\circ} \mathrm{C}\right)$ afforded $202 \mathrm{mg}(87 \%)$ of $\mathbf{8 b}$ as a white solid. $t_{R} \mathbf{8 b}, 10.89 \min (100.0 \%)(\mathrm{HP}-5,15 \mathrm{psi})$

\section{Preparation of 2-(4'-Ethoxycarbonylphenyl)furan (9b)}

Following general procedure III, a solution of $197 \mathrm{mg}$ (1.2 mmol, 1.2 equiv) of $\mathrm{Na}^{+} \mathbf{6}^{-}$in $1.0 \mathrm{~mL}$ of dry toluene under dry argon atmosphere inside a dry box was prepared. To this mixture was added $168 \mu \mathrm{L}(1.0 \mathrm{mmol}, 1.0$ equiv) of ethyl-4-iodobenzoate and $52 \mathrm{mg}(0.05$ mmol, 0.05 equiv) of $\operatorname{Pd}_{2}(\mathrm{dba})_{3} \cdot \mathrm{CHCl}_{3}$. The flask was sealed with a rubber septum and removed from the drybox.

After being stirred at $\mathrm{rt}$ for $1 \mathrm{~h}$, the reaction mixture was diluted with $25 \mathrm{~mL}$ of deionized $\mathrm{H}_{2} \mathrm{O}$, and $20 \mathrm{~mL}$ of EtOAc. The organic layer was separated, and the aqueous layer was washed with EtOAc ( 5 X $25 \mathrm{~mL}$ ). The combined organic layers were dried over $\mathrm{MgSO}_{4}$ and were filtered through \#4 Whatman filter paper. The solvent was removed under reduced pressure to give a dark red residue. A solution of the residue in $0.5 \mathrm{~mL}$ of toluene was loaded onto a silica gel column $(20$ X $100 \mathrm{~mm})$ which was eluted with toluene (20 X $10 \mathrm{~mL}$ fractions). Evaporation of the solvent and further purification by sublimation $\left(0.5 \mathrm{mmHg}, 50{ }^{\circ} \mathrm{C}\right)$ afforded $172 \mathrm{mg}(79 \%)$ of 9b as a white solid. $t_{R}$ 9b, 8.93 min $(100.0 \%)(\mathrm{HP}-5,15 \mathrm{psi})$ 


\section{References}

(1) Whitesides, G. M.; Casey, C. P.; Krieger, J. K. J. Am. Chem. Soc. 1971, 93, 13791389.

(2) Hoye, T. R.; Aspaas, A. W.; Eklov, B. M.; Ryba, T. D. Org. Lett. 2005, 7, 22052208.

(3) Denmark, S. E.; Baird, J. D. Org. Lett. 2004, 6, 3649-3652.

(4) Lee, M.; Ko, S.; Chang, S. J. Am. Chem. Soc. 2000, 122, 12011-12012.

(5) Labadie, S.; Teng, E. J. Org. Chem. 1994, 59, 4250-4254.

(6) Thoresen, L.; Kim, H.; Welch, M. B.; Burghart, A.; Burgess, K. Synlett 1998, 1276-1278.

(7) Takahashi, K.; Suzuki, T.; Akiyama, K.; Ikegami, Y.; Fukazawa, Y. J. Am. Chem. Soc. 1991, 113, 4576-4583.

(8) Amatore, C.; Jutand, A.; Negri, S. J. Organomet. Chem. 1990, 390, 389-398.

(9) Littke, A. F.; Schwarz, L.; Fu, G. C. J. Am. Chem. Soc. 2002, 124, 6343-6348.

(10) Clennan, E. L.: Mehrsheikh-Mohammadi, M. E. Mag. Reson. Chem. 1985, 23, 985-987.

(11) Majima, T.; Pac, C.; Nakasone, A.; Sakurai, H. J. Am. Chem. Soc. 1981, 103, 4499-4508.

(12) Reuter, K. H.; Scott, W. J. J. Org. Chem. 1993, 58, 4722-4726.

(13) Tanis, S. P.; Deaton, M. V.; Dixon, L. A.; McMills, M. C.; Raggon, J. W.; Collins, M. A. J. Org. Chem. 1998, 63, 6914-6928.

(14) Echavarren, A. M.; Stille, J. K. J. Am. Chem. Soc. 1988, 110, 1557-1565. 


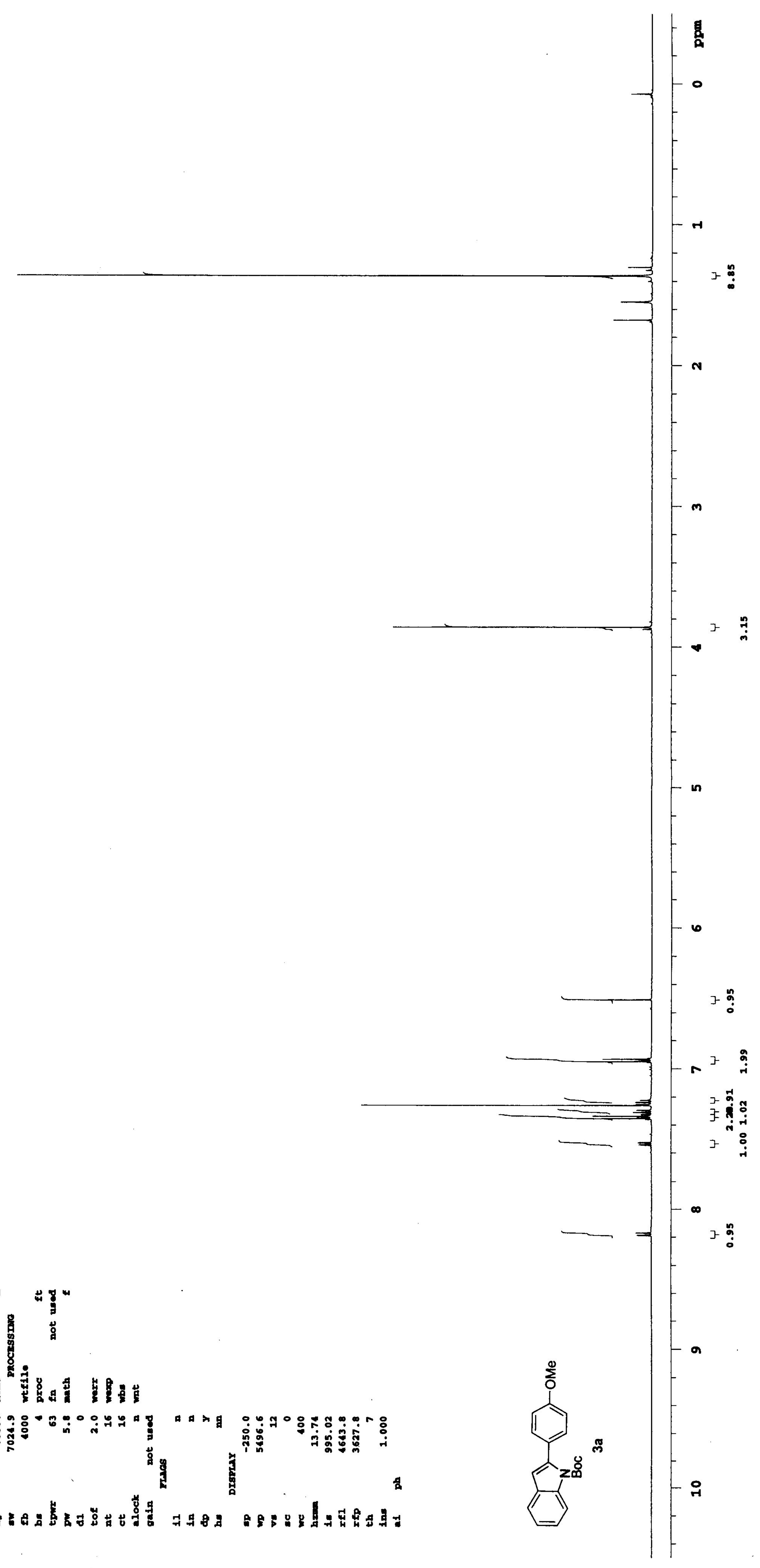




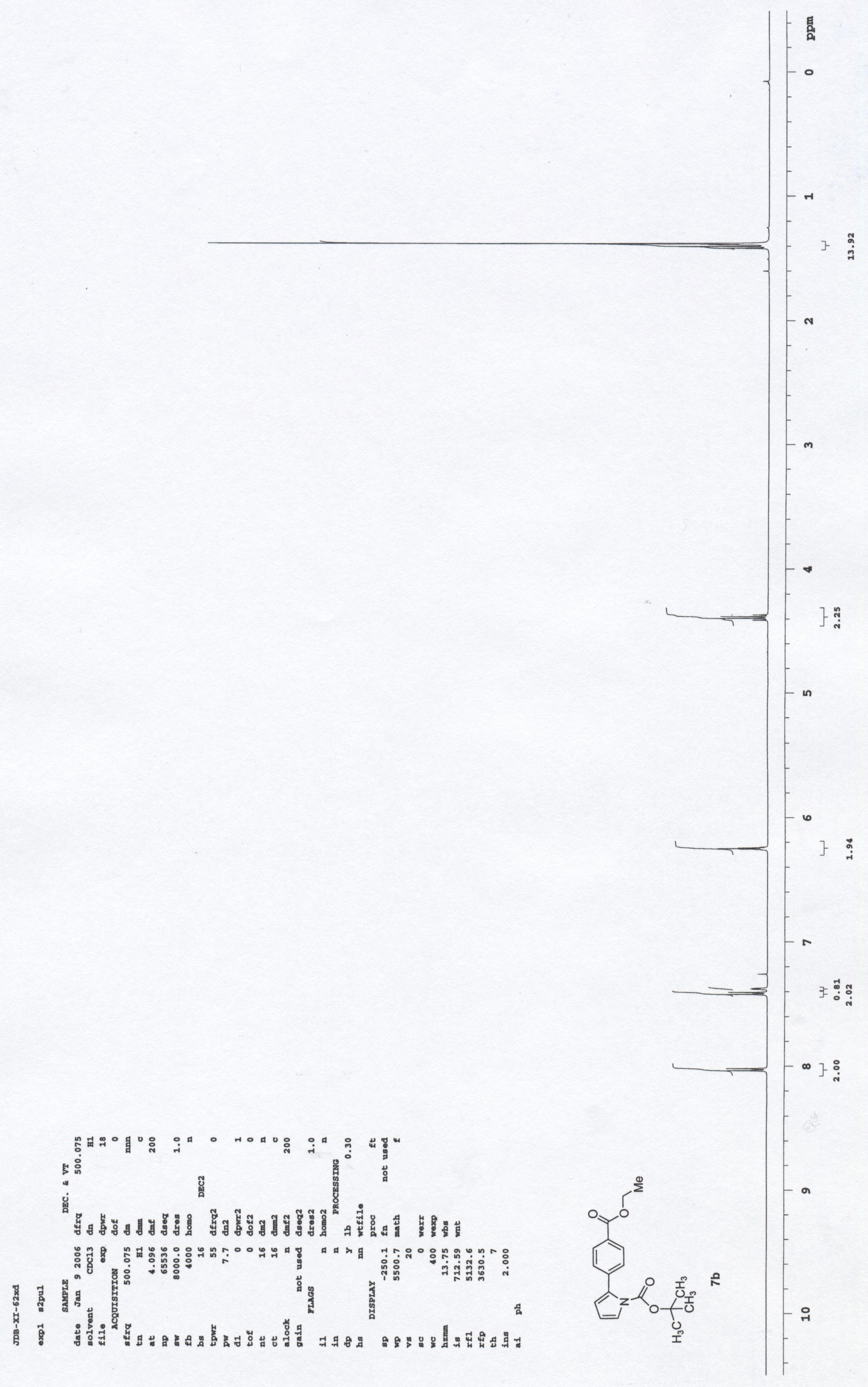

